\title{
The Passalidae collection (Coleoptera) of the Manchester Museum, UK, with a complete type catalogue
}

\author{
Комлекщия Passalidae (Coleoptera) Манчестерского Музея, \\ Великобритания, с полным каталогом типов
}

\author{
Claire Miles \\ КАэр Майлс
}

Department of Entomology, The Manchester Museum, University of Manchester, Oxford Road, Manchester, M13 9PL, UK. E-mail: claire.miles@manchester.ac.uk

KEY WORDS: Passalidae, Passalinae, Aulacocyclinae, type catalogue, Manchester Museum.

КЛЮЧЕВЫЕ СЛОВА: Passalidae, Passalinae, Aulacocyclinae, каталог типов, Манчестерский Музей.

ABSTRACT. The composition of the Manchester Museum's worldwide Passalidae collection is described, with some notes on its history. A catalogue is provided of the 17 holotypes and 41 secondary types (syntypes or paratypes) of Passalidae in the collection, with photographs of all holotypes and their data labels. In total, the collection contains over 8,000 specimens and represents around 300 species and subspecies, approximately $39 \%$ of the described Passalidae world fauna. The types represent 39 species and subspecies.

РЕЗЮМЕ. ОПисаны состав и краткая история мировой коллекции Passalidae Манчестерского Музея. Составлен каталог коллекции, который включает 17 голотипов и 41 вторичных типов (синтипы и паратипы) Passalidae. Приведены фотографии всех голотипов и их этикеток. Всего коллекция насчитывает 8000 экземпляров, относящихся к 300 видам и подвидам, что составляет примерно 39\% мировой фауны Passalidae. Из них 39 видов и подвидов представлены типовыми экземплярами.

\section{Introduction}

The entomology collections at the Manchester Museum contain around 2.5 million insects and are considered to be the third or fourth largest insect depositories in the UK [Logunov, 2010, 2012; Logunov, Merriman, 2012]. The entomological collections date back to 1821, when the museum was founded by the Manchester Society for the Promotion of Natural History. Alberti [2009] provides an account of Manchester Museum's history for the first 100 years (1890-1990). The entomology department was established in 1908, with the appointment of John Ray Hardy (1844-1921) as Senior Assistant Keeper and Curator of Entomology [Logunov, 2012]. Logunov [2012] provides a comprehensive list of the MMUE entomology collections, but particular strengths of the entomology collections include the worldwide Dermaptera collection [see Miles, 2015], C.H. Schills' world Lepidoptera collection, the W.D. Hincks and J.R. Dibb collection of world Coleoptera, and the F. Spaeth collection of Cassidinae [see Higham, 2012]. Alongside the comprehensive entomological collections, the department holds a library of specialist books and reprints, as well as an entomological archive consisting of thousands of documents relating to the Keepers and associated collectors, organised into 34 collections.

In 1996 Colin Johnson, Keeper of Entomology at the time, quoted the number of type specimens in the Manchester Museum collections at 12,000, representing around 2,500 species. Of these, at least 2,300 were holotypes [Johnson, 1996]. However these numbers have significantly increased over the last two decades and this paper is part of work to catalogue all the type material at Manchester Museum in order to encourage and facilitate the use of the collections for research.

The aims of this paper are to provide (1) a description of the composition of the Museum's Passalidae collection and its history and (2) a catalogue of its type material.

\section{Development of the collection}

The Manchester Museum Passalidae collection almost entirely comprises the Hincks and Dibb worldwide Passalidae collection, the creation of Walter Douglas Hincks (1906-1961) (Figs 1-3) and John Rothwell Dibb (1906-1973) (Fig. 1).

John Rothwell Dibb was an insurance surveyor and amateur entomologist with an interest in Coleoptera and, later, Ephemeroptera. He lived in Leeds, Yorkshire, moving to Nottingham in the late 1940s. Between 1926 and 1970 Dibb contributed more than 60 papers to journals and magazines, and was well-known amongst entomologists for his 1948 "Field Book of Beetles". He became a Fellow of the Royal Entomological Society of London in 1930 [Lees, 1974]. 


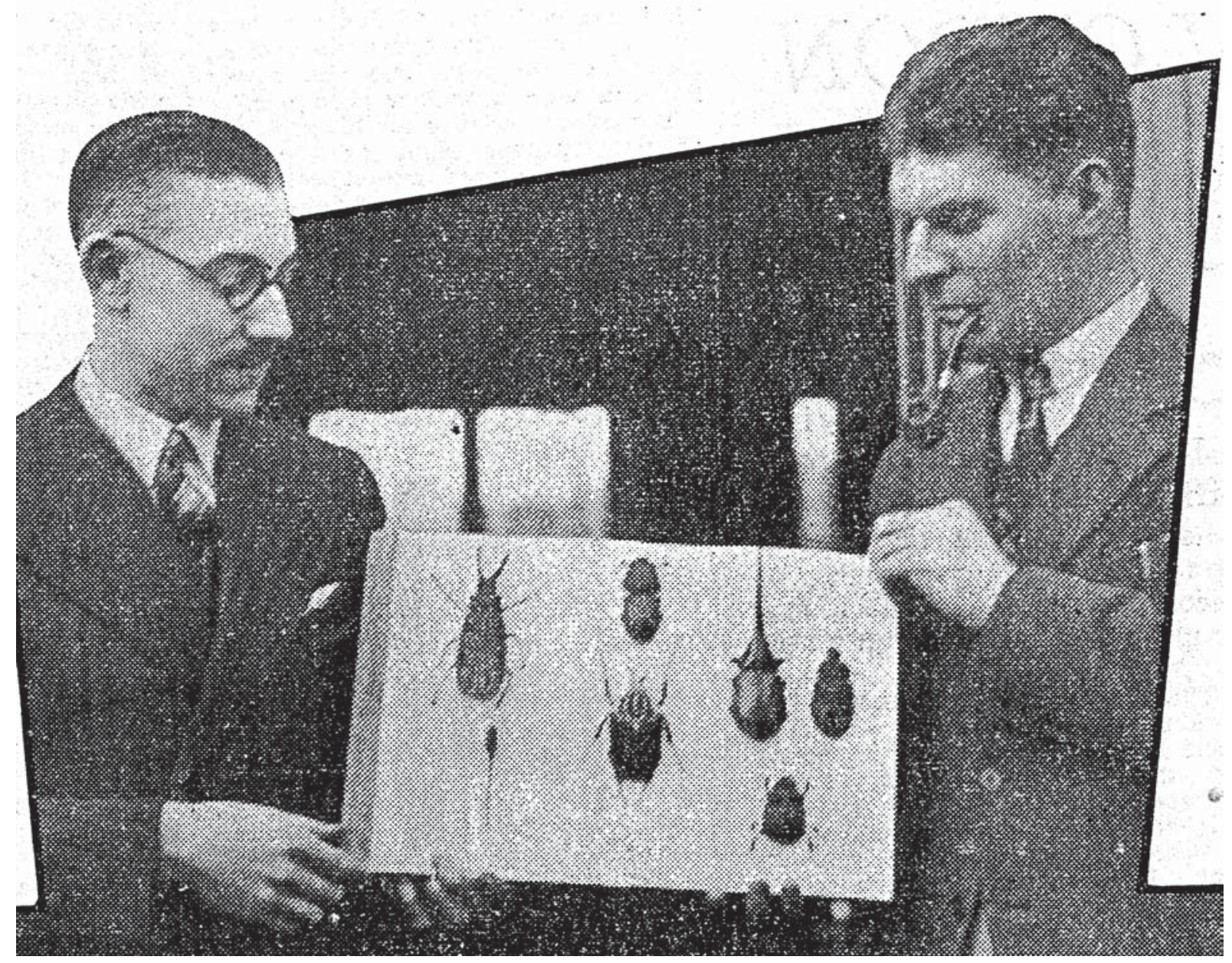

Fig. 1. J.R. Dibb (left) and W.D. Hincks (right) with some of their collection. Photograph from an article in the Yorkshire Evening News, 11 May 1938. Hincks Archive, MMUE, Box 5, No.501.

Рис. 1. Дж.Р. Дибб (слева) и В.Д. Хинкс (справа) с частью своей колекции. Фотография из архива Yorkshire Evening News, 11 Май 1938. Архив Хинкса, MMUE, коробка 5, No.501.

Walter Douglas Hincks trained as a pharmacist and worked for a large firm of manufacturing chemists. He developed expertise particularly in Passalidae, Orthoptera, Chironomidae, Diptera, Cassidinae, parasitic Hymenoptera and Dermaptera [Kloet, 1961]. In 1947, he became Assistant Keeper of Entomology at Manchester Museum, a post he occupied until his death in 1961. By that time he had become a world authority on Passalidae, Dermaptera, and Chrysomelidae, publishing more than three hundred papers and notes [Johnson, 1996]. He developed the Manchester collection to be '...the most important collection in the country after the British Museum and the Hope Department, Oxford, its types and figured specimens running into many thousands.' [Report, 1960-61: 1]. A Fellow of the Royal Entomological Society of London, he served as president of the Society for British Entomology and was a respected member of many regional and local societies.

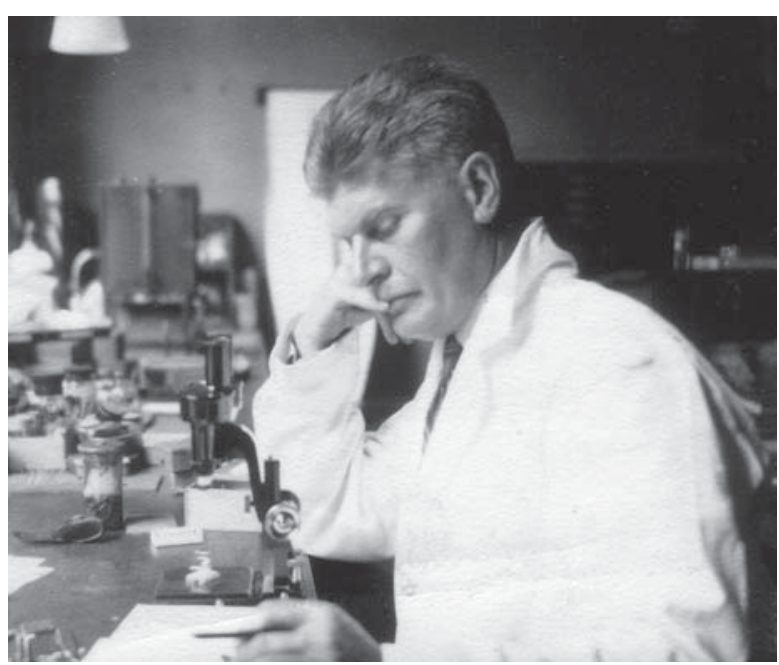

Fig. 2. Walter Douglas Hincks (1906-1961), Keeper of Entomology at the Manchester Museum (1947-1961), photographed in the late 1950s. Archive of Manchester Entomological Society, MMUE, Box 1, No.1.

Рис. 2. Вальтер Дуглас Хинкс (1906-1961), Хранитель Энтомологии Манчестерского Музея (1947- 1961), фотография конца 1950 г. Архив Манчестерского Энтомологического Общества, MMUE, Ящик 1, No.1. 
In a 1938 interview for the Yorkshire Evening News, Hincks and Dibb (or 'Dincks', as the journalist dubbed them) said their enthusiasm for natural history was fired by James Digby Firth F.L.S, a teacher at The Boys' Modern School, Leeds [Murray, 1938]. Digby Firth (1877-1968), known as 'Bug Wullie', was a prominent Yorkshire naturalist and member of several local learned societies, described as a pioneer in teaching nature studies in secondary schools [Leeds University Library, 2016]. According to the article, Hincks and Dibb were introduced to foreign beetles through Ernest Charles Horrell (1870-1944), a bryologist who had been a botany lecturer and then a school biology teacher. His herbarium is at Leeds Museum. Horrell moved to Leeds in 1914 to become manager of one of his brother's clothing shops and immediately joined Leeds Naturalists' Club [Lawley, 2016], of which Hincks was also a member from his youth [Kloet, 1961]. Horrell developed an interest in beetles and built his own collection. Hundreds of worldwide Passalidae specimens in the Hincks and Dibb collection are 'ex. coll. E.C.H'. Hincks named Labienus horrelli for him '...through whose generosity and kindness I have been able to acquire much valuable material in the Passalidae and in other families' [Hincks, 1932: 97].

The genesis of the Hincks and Dibb Passalidae collection is best described by Hincks' friend George Sidney Kloet in Hincks' obituary [Kloet, 1961]:

'Always interested in insects, Douglas joined the Leeds Naturalists' Club and devoted his spare time as a boy to the study of all Orders of insects, and the
Coleoptera in particular were rapidly mastered. Developing a close friendship with John R. Dibb, another enthusiast of his own age, a decision was made to examine some little known group of beetles and test their ability to undertake original research. The Passalidae were chosen and letters were sent all over the world asking for material. In a remarkably short time Hincks and Dibb issued a fine series of papers that established them as the world authorities on this hitherto little known family. In the meantime they amassed one of the largest private collections of foreign beetles in Great Britain and successfully determined a large proportion of the species in spite of the limited library facilities at their disposal.'

Kloet (1904-1981), an amateur entomologist and Manchester businessman, worked with Hincks to produce the influential 24-volume Checklist of British Insects first published in 1945, which was later used to arrange the British collections at the Manchester Museum [Johnson, 1996].

1935 saw Hincks' and Dibb's world Passalidae catalogue published as section 142 of the Coleopterorum Catalogus [Hincks, Dibb, 1935a]. This series, co-ordinated by Sigmund Schenkling, undertook the huge task of collating all described Coleoptera species. Despite the taxonomic development work in the intervening years and the unrelenting discovery of new species, Hincks' and Dibb's contribution is still widely referred to for species distribution, as the only published catalogue of worldwide Passalidae. A supplement was pub-

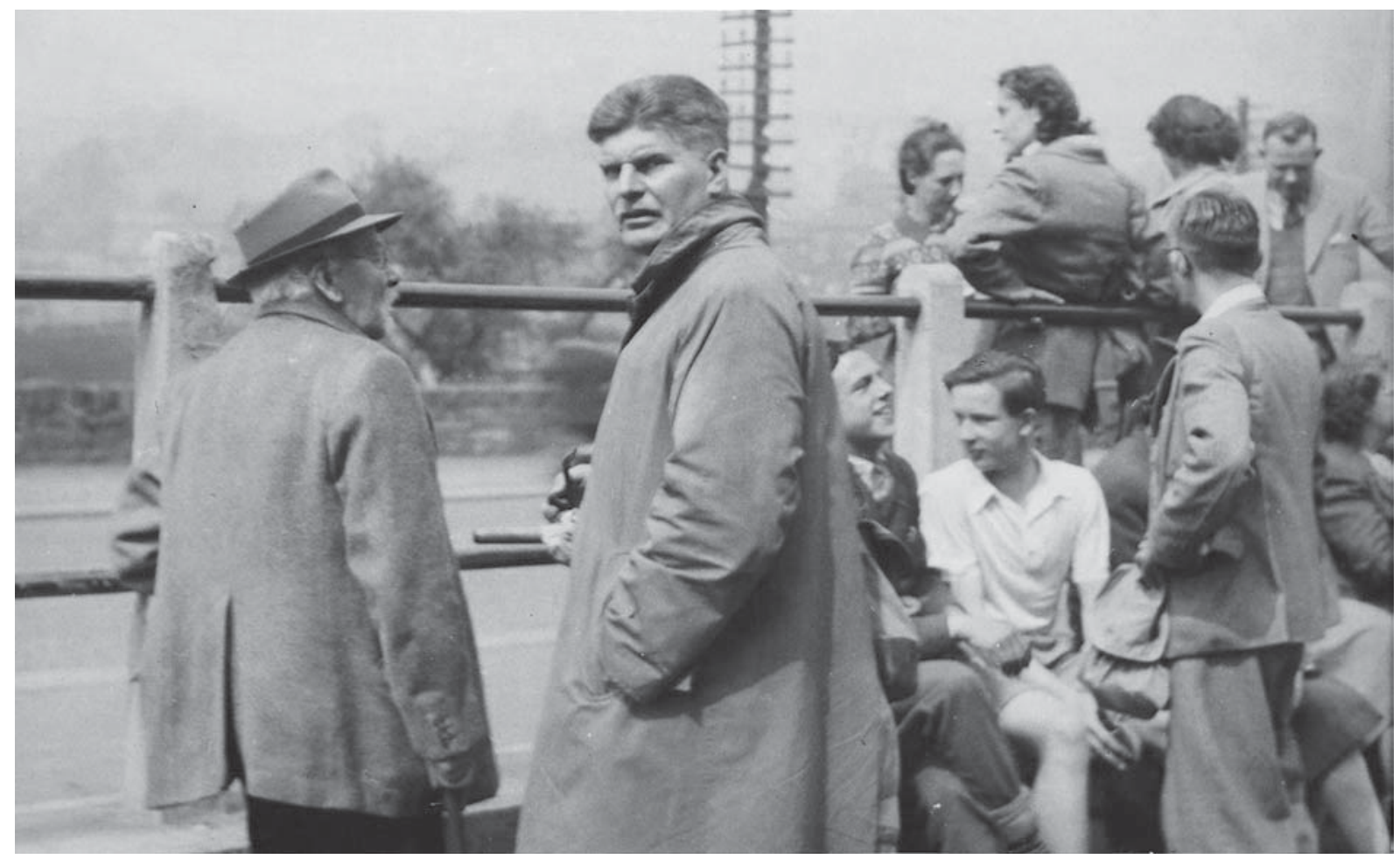

Fig. 3. W.D. Hincks, thought to be on a field trip of the Yorkshire Naturalists' Union, 1940-50s. Photo courtesy of Ray Crossley, FRES.

Рис. 3. В.Д. Хинкс во время полевой экскурсии Йоркширского Клуба Натуралистов, 1940-50 гг. Фотография публикуется с любезного разрешения Ray Crossley, FRES. 
lished in 1958 [Hincks, Dibb, 1958]. The latest large revisionary works, for example those of Stéphane Boucher [2006] continue Hincks' and Dibb's work at the present time.

The Yorkshire Evening News article gave the size of the Hincks and Dibb joint collection as 450,000 insects, 400,000 of which were beetles [Murray, 1938]. During the war, Hincks and Dibb sold a large section of their collections to Leeds Museum, outlining their reasons in a letter to Herbert Ricketts, Curator at Leeds, dated 3 March 1941 [Leeds City Museum, Hincks archive]:

'As you know we have been studying and collecting insects, particularly beetles, for over 20 years and have accumulated very large collections. In the course of our work we have come to specialize on certain groups. We feel that we must now give up our general collections and concentrate all our energies on these specialities...having spent our reserves of cash in this way and wishing to go on with our work we feel we should ask for a purely nominal sum in exchange for this material as a 'subscription' towards our future research'.

A list attached to the letter detailed the offer of 50,000 Coleoptera - Curculionidae, Elateridae, Heteromera, Malacodermata and other groups. Being one of their 'specialities', the Passalidae was one of the collections they retained. This was fortunate for the collection, because 12 days after this letter Leeds City Museum was struck by a bomb during an air raid, causing considerable damage to the invertebrate collections [Norris, 1995]. Luckily much of the transferred material survived and Hincks subsequently arranged for the transfer of many of these collections from Leeds City Museum to Manchester Museum when he was Keeper at Manchester.

Manchester Museum acquired the Hincks and Dibb Passalidae collection following Hincks' death in 1961, when it was purchased from his widow. The collection came in twenty cabinet drawers along with forty store boxes of other duplicate and undetermined material. According to the Museum report of 1961-62, the collection included 'only some thirty types and paratypes' but was considered to be second only to the British Museum (Natural History) collection [Report, 196162: 14]. Figs 5-6 show the current storage of the Passalidae collection.

The main source of information on Hincks and Dibb's acquisition of the specimens comes from the collection itself and from the Hincks archive. Inevitably Dibbs' side of the story is less well-documented.

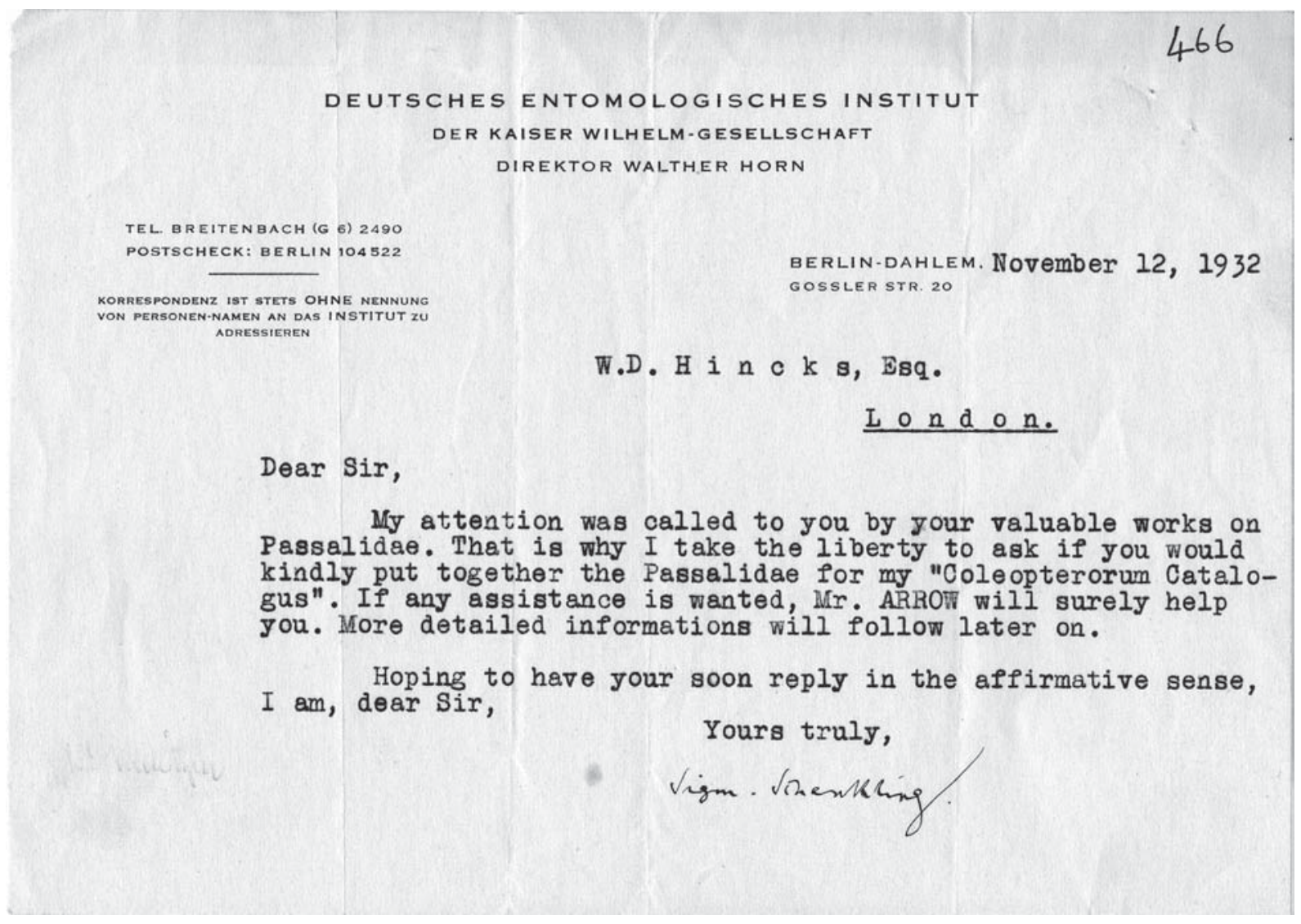

Fig. 4. Letter from Sigmund Schenkling to W.D. Hincks dated 12 Nov. 1932, inviting him to contribute the Passalidae section of the Coleopterorum Catalogus. Hincks Archive, Box 2, No. 466.

Рис. 4. Письмо Зигмунда Шенклинга В.Д. Хинксу от 12 ноября 1932, в котором ему предлагается опубликовать раздел по Passalidae в Coleopterorum Catalogus. Архив Хинкса, MMUE, коробка 2, No.466. 


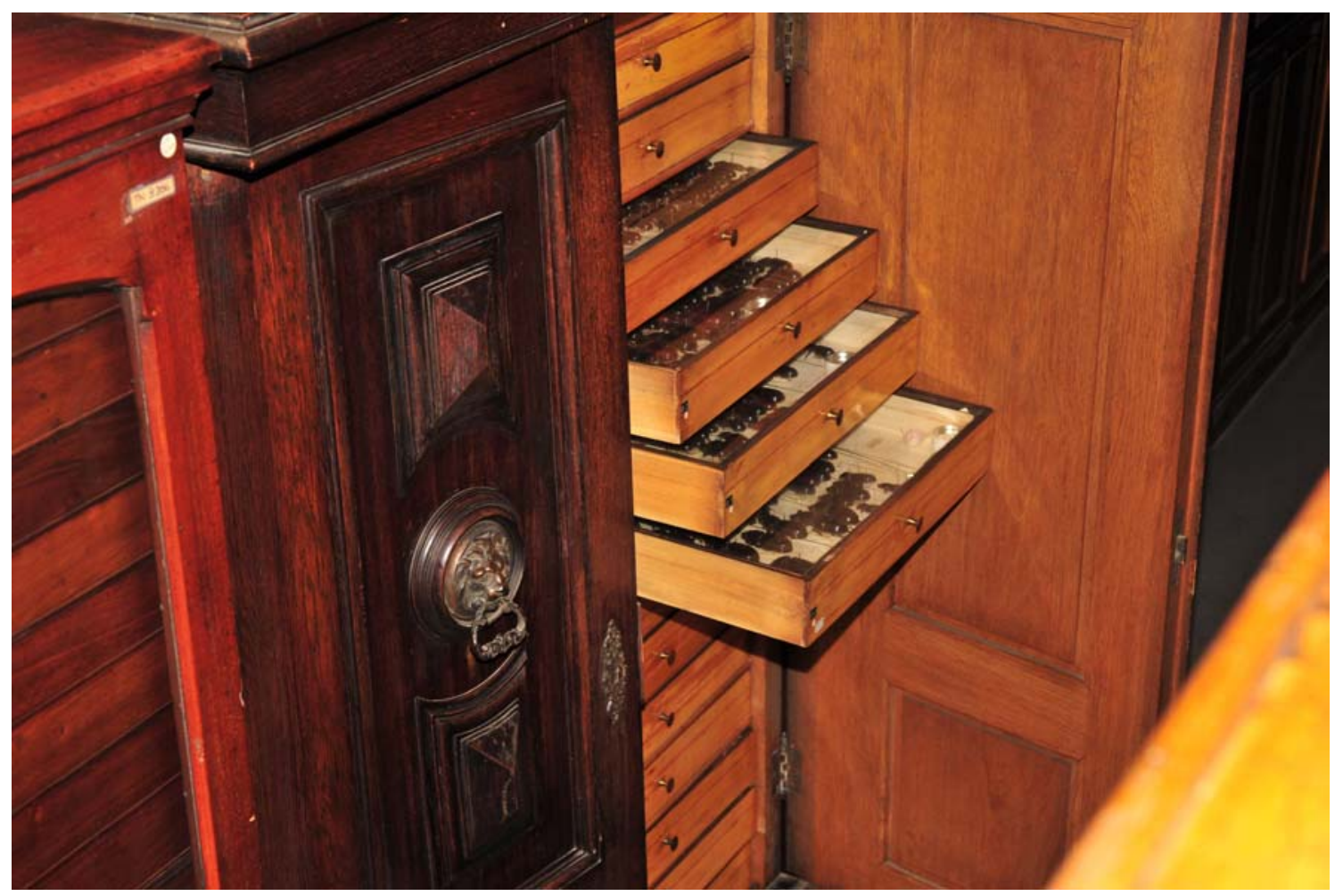

Fig. 5. Cabinet 1, with its imposing doors, which currently contains the largest part of the Manchester Museum Passalidae collections drawers $1-30$.

Рис. 5. Шкаф 1 с внушительными дверцами, в котором в настоящее время хранится большая часть коллекции Раssalidae Манчестерского Музея - ящики 1-30.

The Hincks archive totals 611 items in five boxes. These include 94 of his published papers, 26 notebooks and 453 letters, as well as manuscripts on the Passalidae and his diaries from 1948-49 and 1956 [see also Logunov, 2012].

There are 75 letters specifically relating to Hincks' work on Passalidae. Notable correspondents include Frederic Henry Gravely (1885-1965) who carried out the pioneering work on classification of the Passalidae, and the British entomologist and collector Lucy Evelyn Cheesman (1882-1969) who collected insects for the British Museum (Natural History) on her 1933 expedition to Papua. Hincks published an analysis of the 79 Passalid specimens from the 42,000 insects she brought back [Hincks, 1937], representing eight genera and 14 species, and he named Labienus cheesmanae in her honour [Hincks, 1935]. Hincks also corresponded with the French entomologist René Oberthür (1852-1944), whose immense collections, designated an historic monument, were acquired by the Museum National d'Histoir Naturelle, Paris in 1952. These letters relate to Hincks' examination of type specimens from Kuwert's collection in Oberthür's possession, mostly from Madagascar. Oberthür also sent Hincks ' ... two smaller boxes with insects (Passalidae and Lucanidae), for your collection' [Hincks archive, Box 2, No. 420].

The Passalidae collection grew through exchange with associates such as Horrell; through purchase from dealers; through contacts such as Oberthür, made in his taxonomic review work, and through retaining duplicate material from identification work. From Hincks' correspondence and notebooks, he was certainly receiving such identification requests from the early $1930 \mathrm{~s}$ until 1959, from museums, universities and entomological institutions all over the world wishing to take advantage of his expertise.

The largest proportion of specimens came from the insect trading company Staudinger and Bang-Haas, Dresden (operating 1859-1948). At least half of these are South American, others are Australian, Oriental and Nearctic.

Another group come from the T.G. Bishop Coleoptera collection at the University of Glasgow. Hincks' 'Determination' notebook lists 214 specimens of 78 species identified 1942-1946 [Hincks archive, Box 4, No. 486].

Another 200 specimens came from the collection of Dr. Nodier via dealer Mme. J. Clermont of Paris in 1931, representing 100 species 'trés soigneé et bien déterminé' [Hincks Archive, Box 5, No. 500]. It seems likely this was the French naval doctor Charles Mathurin Simon Nodier (1851-1930) [Gilbert, 2007]. Aulacocylus gravelyi Dibb, 1933 and Publius oberthuri Hincks 1933 (now Veturius (Ouayana) oberthuri) were described from this group. Specimen labels include the names of entomologist and insect dealer Otto Staudinger 


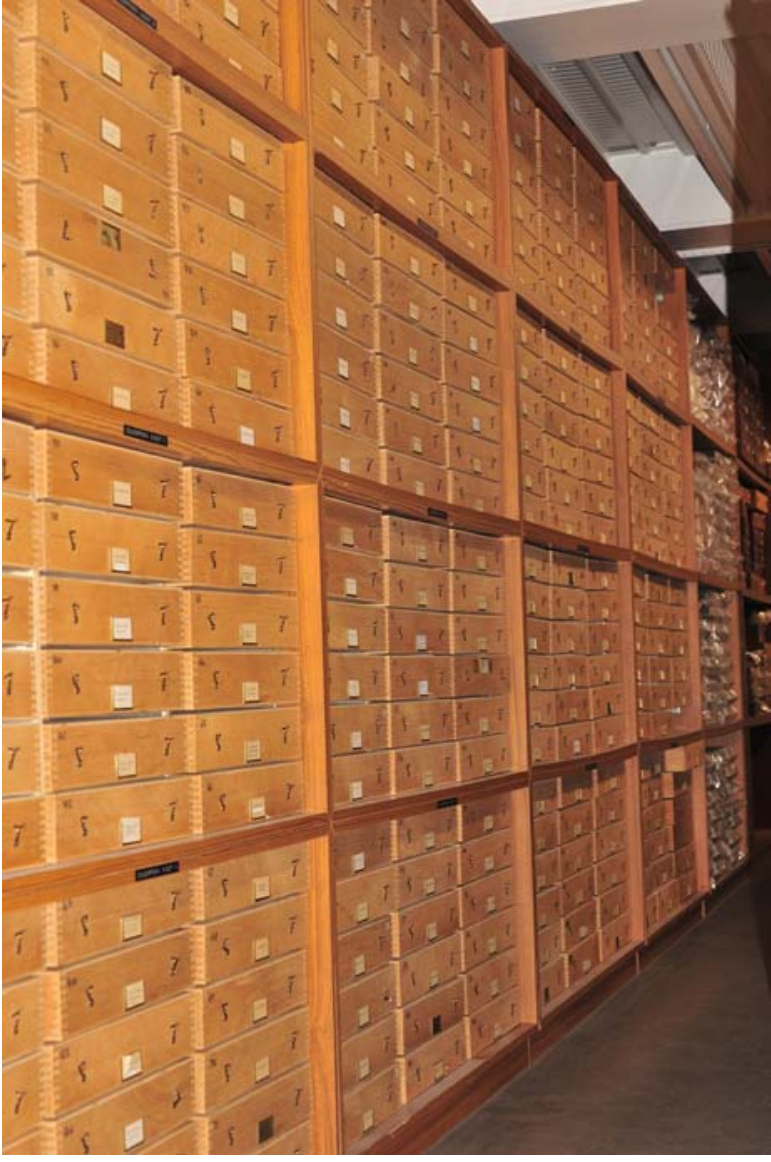

Fig. 6. The 31 store boxes containing Passalidae specimens awaiting determination are shown at the left hand of the image.

Рис. 6. 31 ящик с экземплярами Passalidae, которые нуждаются в определении, показаны в левой части фотографии.
(1830-1900), Hermann Rolle (1864-1929), Claude Roussel, F. Schneider and Edgar Aubert de la Rue (1901-1991). Very few specimens are dated but two older specimens include two Aulacocyclus parryi Hope, collected by the naturalist and explorer Luigi Maria d'Albertis in his 1876-7 expedition to chart the Fly River, Papua New Guinea [d'Albertis, 1880].

A group of 25 South American specimens came from the entomologist Dr. Hermann Luederwaldt (18651934) of the Museu Paulista, Brazil, whose publications include his monograph on Brazilian Passalidae and a revision of the genus Paxillus [Luederwaldt, 1931, 1934]. Hincks named Passalus luederwaldti in his honour [Hincks, 1940]. Luederwaldt's beetles came to Hincks via Bernard Benesh (1891-1964), a Chicago steel mill worker who studied Lucanidae and collaborated with the Field Museum of Natural History in Chicago [Hincks Archive, Box 5, No. 500].

One of the oldest specimens in the collection is Passalus henrici Rosmini, collected in Caracas in 1851. Some of the newest are specimens collected in 2014 in Costa Rica by Dmitri Logunov, Manchester Museum's current Curator of Arthropods, yet to be determined.

Other recent specimens have been contributed to the collection by researchers working on taxonomic reviews, notably Dr. Stéphane Boucher, Paris, and Prof. Masahiro Kon, Japan. Boucher donated paratypes of Gonatas hebridalis, G. vanuatuensis, Ophrygonius boxer, Veturius hincksi and Labienus opalus to the collection. He dedicated the genus Hincksius to Hincks' memory, describing him as a 'spécialiste éminent des Passalides du Globe' to whom was owed the discovery of many species [Boucher, 1993a]. Boucher and Kon have also determined hundreds of specimens in the collection.

$$
\begin{aligned}
& 30 \\
& \text { WE DNES DA Y } \\
& \text { St. Andrew's Day }
\end{aligned}
$$

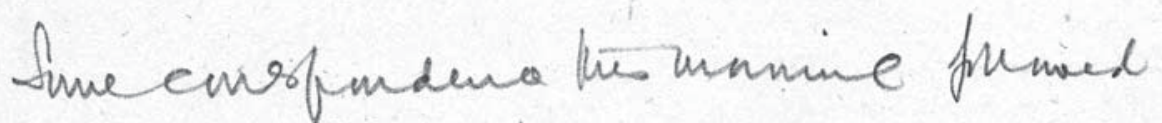

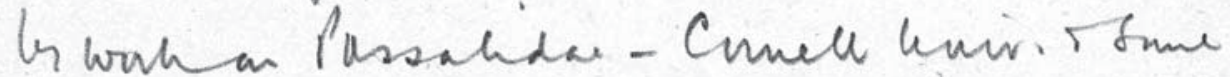

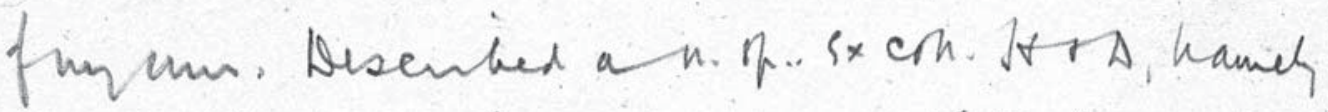

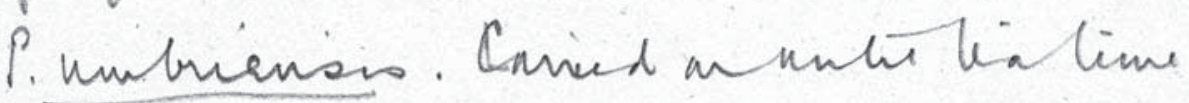

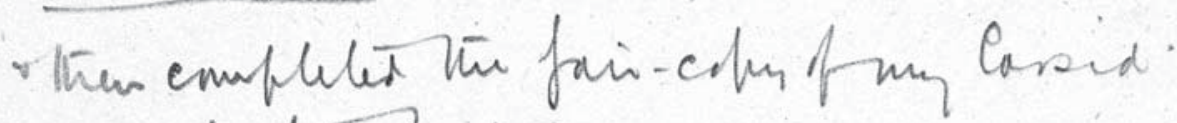

$$
\begin{aligned}
& \text { nnumela lime faph. }
\end{aligned}
$$

Fig. 7. A day in the life ... Extract from Hincks' diary 30 November 1949. 'Some correspondence this morning followed by work on Passalidae — Cornell Univ. and some of my own. Described a n. sp. ex. coll. H \& D, namely P. umbriensis...'. Hincks Archive, Box 4, No.488.

Рис. 7. День из жизни ... выдержка из дневника Хинкса от 30 ноября 1949. 'Утром написание писем, за которым последовала работа с Passalidae - из Корнельского ун-та и своими собственными. Описал новый вид из коллекции $\mathrm{H} \& \mathrm{D}$, а именно $P$. umbriensis...'. Архив Хинска, коробка 4, №.488. 


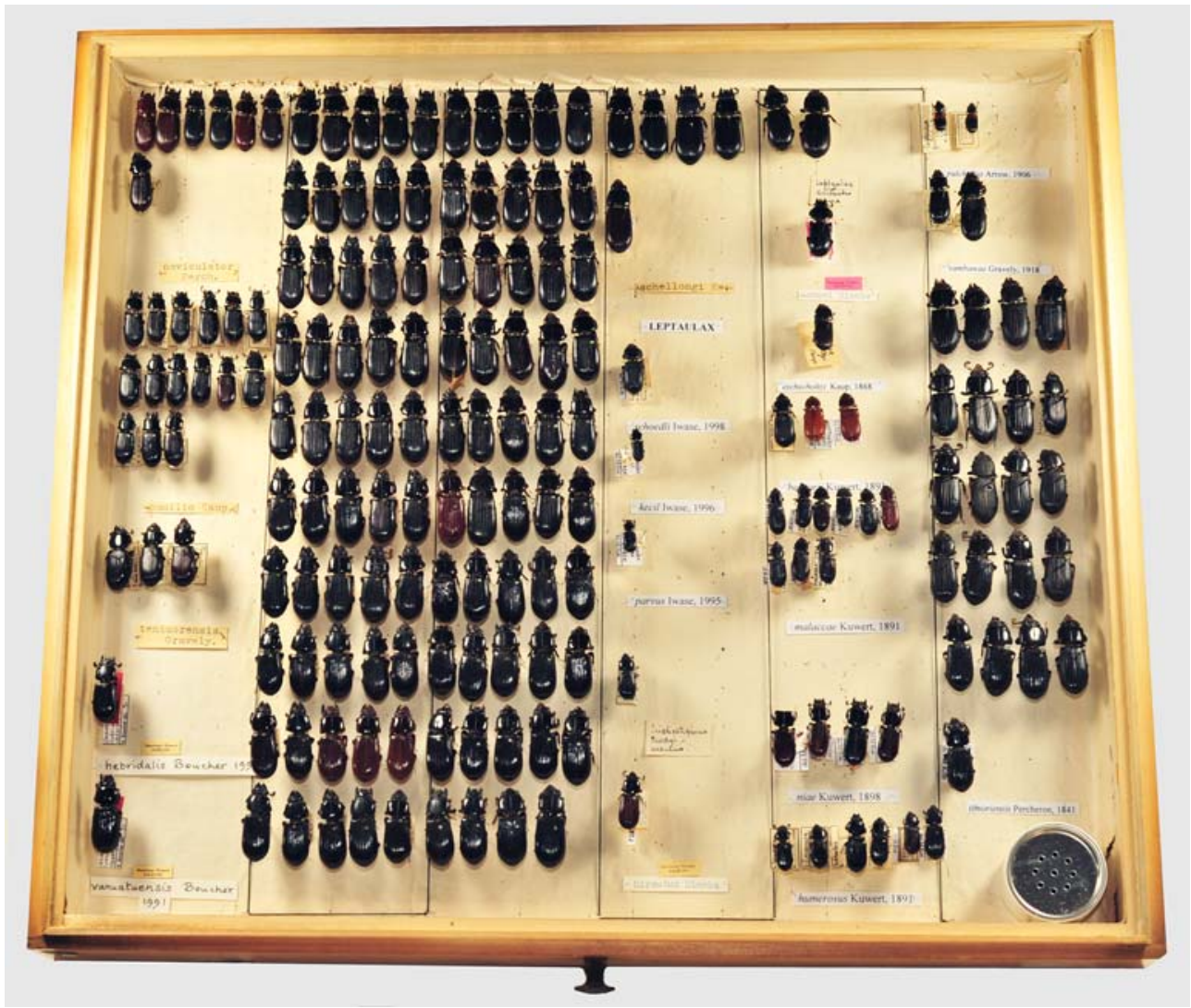

Fig. 8. Drawer 28 in cabinet 1 contains some of the more recent determinations and donations.

Рис. 8. Ящик 28 из шкафа 1 содержит некоторые из недавно подаренных и определённых экземпляров.

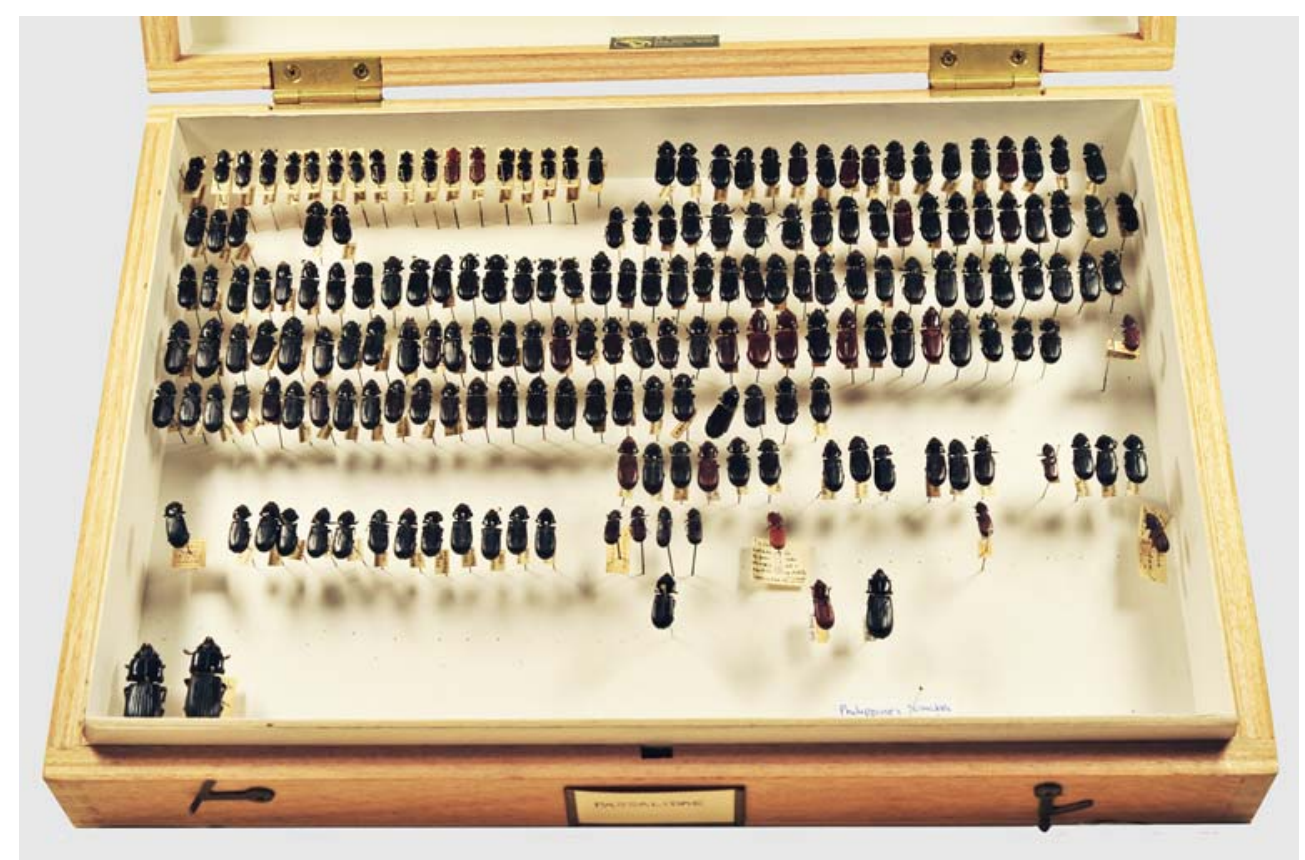

Fig. 9. An example of one of the wooden store-boxes containing part of the Hincks and Dibb Passalidae collection. Box 73 - some of the oriental beetles.

Рис. 9. Образец одной из деревянных коробок, в которых хранится часть коллеции Раssalidae Хинкса и Диббса. Ящик 73 некоторые ориентальные жуки. 
Table 1. Specimens in the Hincks and Dibb worldwide Passalidae collection determined to species level. Таблица 1. Экземпляры мировой коллекции Passalidae в коллекции Хинска и Диббса, определённые до вида.

\begin{tabular}{|c|c|c|c|c|c|}
\hline \multirow[b]{2}{*}{ Subfamily } & \multirow[b]{2}{*}{ Tribe } & \multicolumn{3}{|c|}{ No. of species and subspecies } & \multirow[b]{2}{*}{$\begin{array}{c}\text { No. of } \\
\text { specimens }\end{array}$} \\
\hline & & $\begin{array}{l}\text { MMUE } \\
\text { collection }\end{array}$ & World fauna* & $\begin{array}{c}\text { MMUE's } \\
\text { representation of } \\
\text { World Fauna } \\
(\%)\end{array}$ & \\
\hline \multirow{2}{*}{ Aulacocyclinae } & Aulacocyclini & 23 & 38 & 61 & 323 \\
\hline & Ceracupini & 3 & 8 & 38 & 5 \\
\hline \multirow{5}{*}{ Passalinae } & Leptaulacini & 16 & 73 & 22 & 1080 \\
\hline & Macrolinini & 95 & 208 & 46 & 1280 \\
\hline & Passalini & 85 & 195 & 44 & 1421 \\
\hline & Proculini & 59 & 239 & 25 & 594 \\
\hline & Solenocyclini & 27 & 35 & 77 & 782 \\
\hline Total & & 308 & 796 & 39 & 5485 \\
\hline
\end{tabular}

*After Schoolmeesters [2016].

The collection has contributed to publications such as those by P. Reyes-Castillo [Reyes-Castillo, Schuster, 1983], S. Boucher - notably his important revisionary work on the evolution and phylogeny of the Passalidae [Boucher, 2006], and by M. Kon and colleagues, for example in the re-description of Ophrygonius minor (Gravely) [Kon, 2001], the redescription of Leptaulax arrowi [Kon, Johki, 2004] and most recently, the re-evaluation of Leptaulax niae as a valid species [Kon et al., 2016].

\section{Material and methods}

An updated count was made of all the constituent parts of the collection. For the type specimens, transcriptions were made of the labels, and accession numbers were allocated. The type status of each specimen was assessed with reference to the original description. All holotypes were photographed using a Nikon D700 camera (Figs 10-26).

The primary and secondary types of Passalidae in the Manchester Museum collection are listed, arranged alphabetically by species name as originally described.

Each entry includes:

Species name Author, (Genus) in original combination Figure reference

Taxon name in original combination. Literature citation for the original description with pagination, figures and plates.

TYPE MATERIAL. Type/s of specimens, number, gender (where known) and accession number/s. Where the status of material labelled 'co-type' has been deduced, this is outlined in the REMARKS. for the entry.

LABEL DATA. A transcription of the specimen labels except where illegible ([illeg.]). A slash indicates the end of a line (/) and a double slash indicates a separate label (//).

CURRENT NOMENCLATURE. Taxonomic nomenclature follows Boucher 2006, Reyes-Castillo 1970 and Hincks, Dibb 1935a, 1958 unless otherwise indicated.
REMARKS. Including nomenclatural changes and any supplementary information regarding the locality, the acquisition of the specimen and location of other types.

Abbreviations:

MMUE - Manchester Museum, The University of Manchester, Manchester, UK

MNHN - Muséum National d'Histoire Naturelle, Paris.

All specimens are dried and pinned unless otherwise stated.

\section{Results}

Composition of the worldwide Passalidae collection (Accession number F2439)

308 species and subspecies are represented in the collection, approximately $39 \%$ of the Passalidae world fauna. The Passalidae collection at Manchester Museum comprises 8,026 specimens:

Table 2. Passalidae specimens at Manchester Museum determined only to genus level.

Таблица 2. Экземпляры Passalidae из Манчестерского музея, определённые только до рода.

\begin{tabular}{|l|l|c|c|}
\hline \multirow{2}{*}{ Subfamily } & \multicolumn{1}{|c|}{ Tribe } & $\begin{array}{c}\text { No. of } \\
\text { genera }\end{array}$ & $\begin{array}{c}\text { No. of } \\
\text { specimens }\end{array}$ \\
\hline \multirow{3}{*}{ Aulacocyclinae } & Aulacocyclini & 3 & 76 \\
\cline { 2 - 4 } & Ceracupini & 0 & 0 \\
\hline \multirow{5}{*}{ Passalinae } & Leptaulacini & 1 & 95 \\
\cline { 2 - 4 } & Macrolinini & 11 & 614 \\
\cline { 2 - 4 } & Passalini & 3 & 585 \\
\cline { 2 - 4 } & Proculini & 8 & 72 \\
\cline { 2 - 4 } & Solenocyclini & 3 & 383 \\
\hline \multirow{2}{*}{ Total } & & $\mathbf{1 8 2 5}$ \\
\hline
\end{tabular}


Table 3. Number of Passalidae specimens determined only to genus level or undetermined, by geographical region (where locality data is available)

Таблица 3. Количество экземпляров Passalidae определённых до рода или неопределённых по географическим регионам (там, где имеются этикетки).

\begin{tabular}{|l|c|}
\hline Region & No. of specimens \\
\hline Afrotropical & 337 \\
\hline Australasian & 393 \\
\hline Nearctic & 21 \\
\hline Neotropical & 677 \\
\hline Oriental & 727 \\
\hline Palearctic & 7 \\
\hline No data & 379 \\
\hline Total & $\mathbf{2 5 4 1}$ \\
\hline
\end{tabular}

1. 5,485 dry, pinned specimens housed in 32 glasslidded drawers in two cabinets, arranged taxonomically (Figs 5, 8).

2. 2,541 dry, pinned specimens in 31 store-boxes, partially arranged geographically. Of these 716 are undetermined and 1,825 are determined to genus level (Figs 6, 9).

At MMUE, type material is kept within the main collection. In total there are 17 holotypes and $41 \mathrm{sec}-$ ondary types (syntypes or paratypes) representing 39 species and subspecies (Table 4) of which 23 were described by Hincks between 1932 and 1956, four by Dibb between 1933 and 1948, and nine by Boucher between 1991 and 2006 .

Type catalogue of the Passalidae collection at Manchester Museum.

aquilonalis Boucher, (Veturius)

Veturius aquilonalis Boucher, 2006: 432, fig. 105. TYPE MATERIAL. Paratypes (5), F2439.9-13.
LABEL DATA. Vet. / aquilonalis / Paratype / S. Boucher det. 04 // Chiriqui / Panama. // Ex Staudinger \& Bang Haas, Dresden. / / Mus: Hincks \& Dibb

CURRENT NOMENCLATURE. Passalinae, Proculini, Veturius (Veturius) aquilonalis Boucher, 2006.

REMARKS. Placed in the platyrhinus species group by Boucher [2006].

\section{arrowi Hincks, (Leptaulax)}

Fig. 10.

Leptaulax arrowi Hincks, 1933a: 12, fig. 3.

TYPE MATERIAL. Holotype, F2439.47.

LABEL DATA. Holotype / Leptaulax arrowi / Hincks, 1933 [modern, printed label]. // Mt. Balis // Ex Staudinger \& Bang Haas, Dresden // 5073.

CURRENT NOMENCLATURE. Passalinae, Leptaulacini, Leptaulax arrowi Hincks, 1933.

REMARKS. Hincks (1933a: 12) suggests Mt. Balis ' $\ldots=\mathrm{Mt}$. Bali in island of Bali?' but states 'It was received from the firm of Staudinger in a box of other Leptaulax chiefly from the Philippines and New Guinea.' In their redescription of Leptaulax arrowi, Kon, Johki [2004: 339] consider the specimen most closely resembles $L$. uenoi from the Philippines and suggest that the type locality may be in the Philippines.

\section{beneshi Hincks, (Passalus)}

Fig. 11.

Passalus (Pertinax) beneshi Hincks, 1950: 1041, fig. 4.

TYPE MATERIAL. Holotype ( $\left.\sigma^{7}\right)$, F2439.48.

LABEL DATA. Passalus / (Pertinax) Type / beneshi Hincks / det. W.D. Hincks. // X X Plantation / Rep of Panama / 2/17/30 // Blackwelder / Collection // $\sigma^{7}$ dissec / S. Boucher det. 2012.

CURRENT NOMENCLATURE. Passalinae, Passalini, Pertinax beneshi (Hincks, 1950).

REMARKS. 1. Transferred from Passalus to Pertinax (as genus) by Boucher [2015: 118].

2. Hincks [1950: 1043] remarks, 'This interesting little Passalid was kindly given to me some years ago by my friend Mr. Bernard Benesh of Sunbright, Tenn., a specialist on the Lucanidae. It has remained in the Hincks and Dibb collection unmatched and undescribed, and I have pleasure in naming it in honour of Mr. Benesh, who has helped me most generously by the gift of material ..'.

Table 4. Number of Passalidae species and subspecies represented by type specimens at the Manchester Museum. Таблица 4. Количество видов и подвидов Passalidae, представленных типовыми экземплярами в Манчестерском Музее.

\begin{tabular}{|c|c|c|c|c|c|c|c|}
\hline \multirow[b]{2}{*}{ Subfamily } & \multirow[b]{2}{*}{ Tribe } & \multicolumn{5}{|c|}{ No. of species and subspecies } & \multirow[b]{2}{*}{$\begin{array}{c}\text { No. of } \\
\text { specimens }\end{array}$} \\
\hline & & $\begin{array}{c}\text { Holotype } \\
\text { only }\end{array}$ & $\begin{array}{c}\text { Holotype } \\
+ \\
\text { Paratype }\end{array}$ & $\begin{array}{c}\text { Paratype } \\
\text { only }\end{array}$ & $\begin{array}{c}\text { Syntype } \\
\text { only }\end{array}$ & Total & \\
\hline \multirow{2}{*}{ Aulacocyclinae } & Aulacocyclini & 2 & 0 & 0 & 0 & 2 & 2 \\
\hline & Ceracupini & 0 & 0 & 0 & 1 & 1 & 1 \\
\hline \multirow{5}{*}{ Passalinae } & Leptaulacini & 1 & 0 & 1 & 0 & 2 & 2 \\
\hline & Macrolinini & 3 & 2 & 9 & 1 & 15 & 22 \\
\hline & Passalini & 3 & 3 & 2 & 0 & 8 & 13 \\
\hline & Proculini & 0 & 2 & 7 & 0 & 9 & 16 \\
\hline & Solenocyclini & 1 & 0 & 1 & 0 & 2 & 2 \\
\hline & & 10 & 7 & 20 & 2 & 39 & 58 \\
\hline
\end{tabular}




\section{boxer Boucher (Ophrygonius)}

Ophrygonius boxer Boucher, 1993b: 162, figs 13, 18, 21.

TYPE MATERIAL. Paratype, F2439.31.

LABEL DATA. Ophrygonius / boxer / Paratype / S. Boucher det. 91. // Indes Orientales / Mts. Kodeicanel / J. Castets 1886. // Museum Paris.
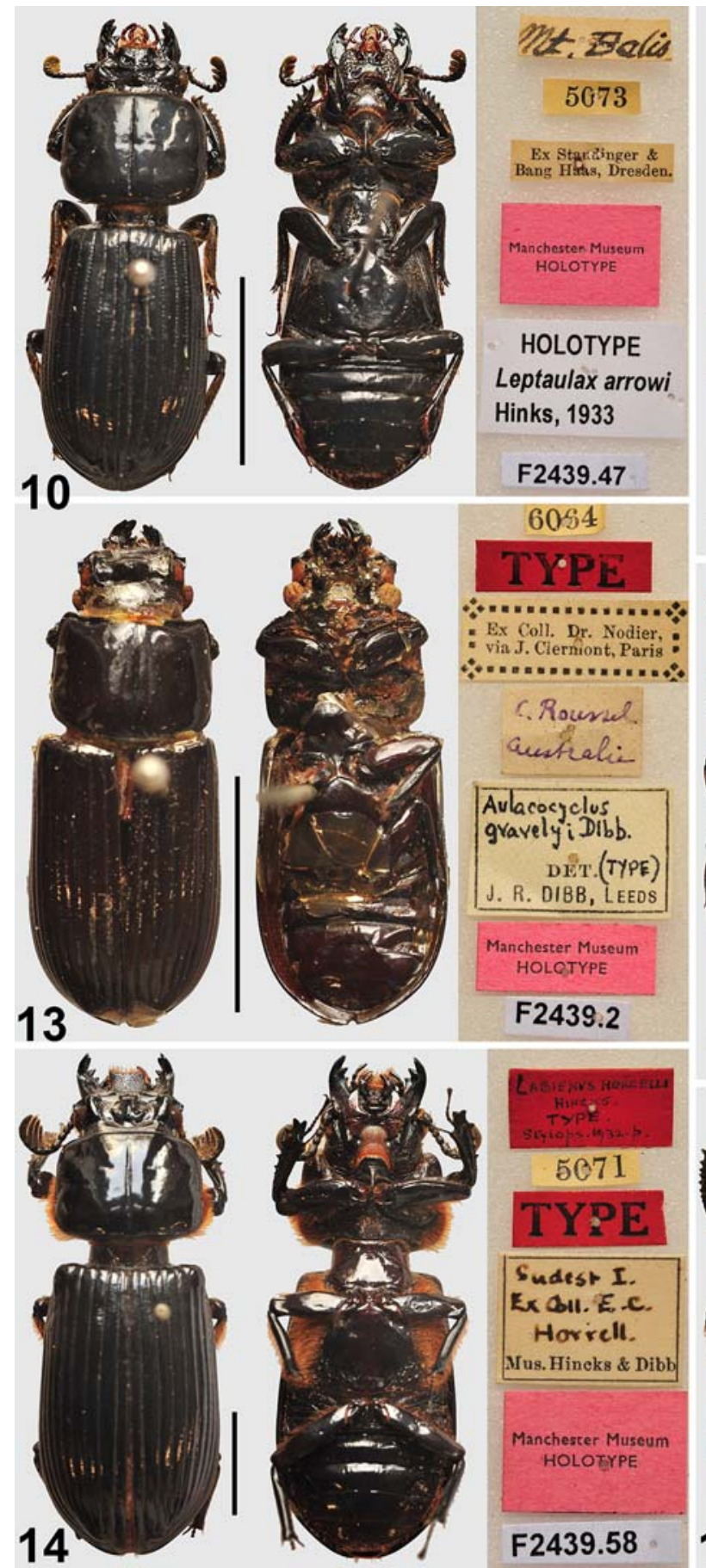

CURRENT NOMENCLATURE. Passalinae, Macrolinini, Ophrygonius boxer Boucher, 1993.

REMARKS. Donated to MMUE by S. Boucher.

cheesmanae Hincks (Labienus)

Labienus cheesmanae Hincks, 1935: 53.
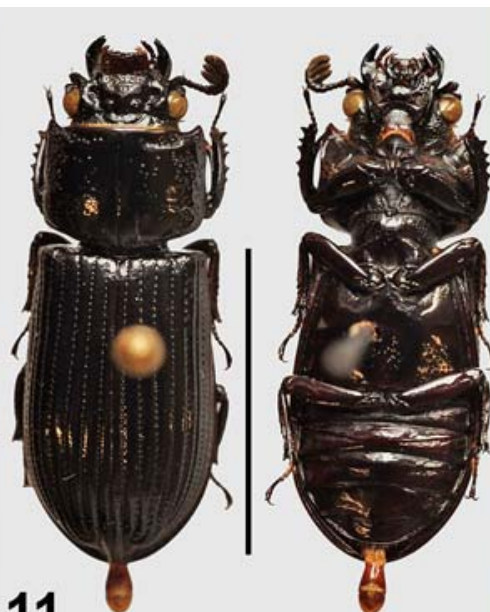

X X Plantation Rep $9 f>136$

B1ackwelder Collection

Via B.Buesh Norlt Chieago

Passalus (Pertinax) TyPa beneshibinichs det.W.D.Hincles

Manchester Muscum HOLOTYPE

of dissec ${ }^{\circ}$

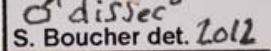

F2439.48
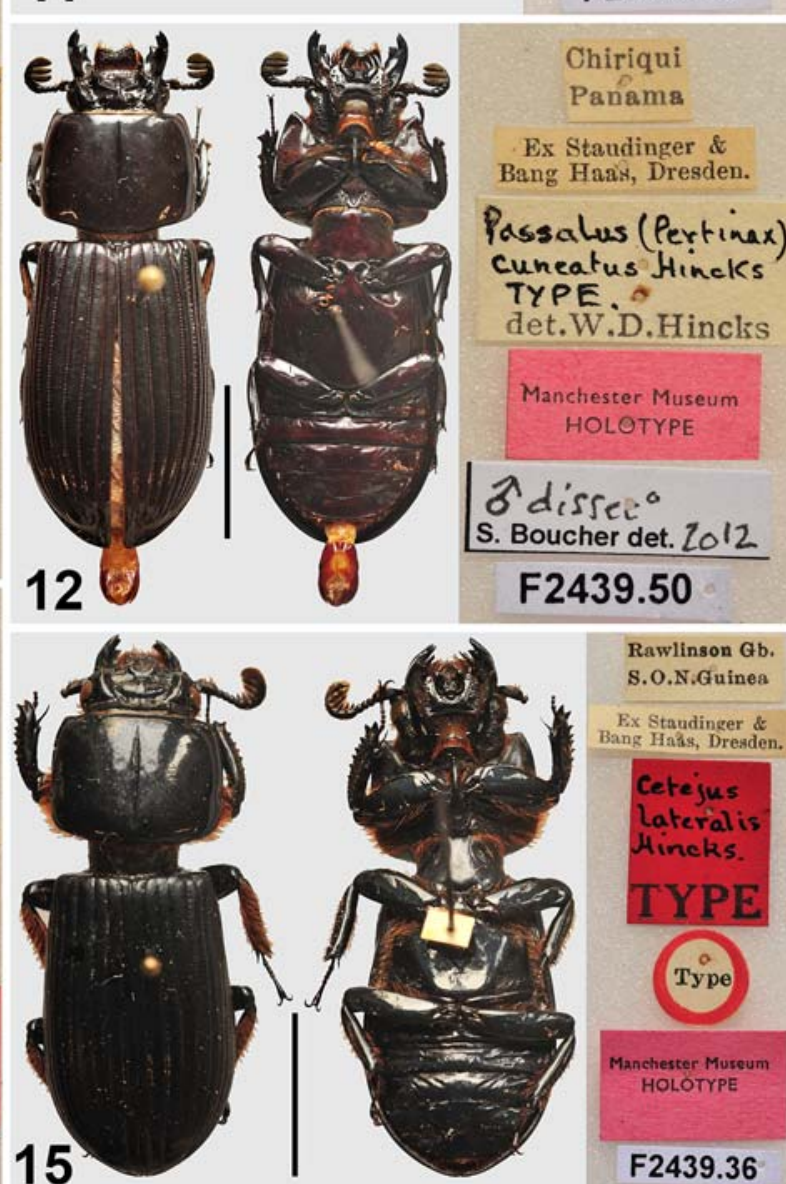

Rawlinson $\mathrm{Gb}$ S.O.N.Guinea

Ex Staudinger \& Cotals, Dresden.

Cetejus Lateral is Hincks. TYPE
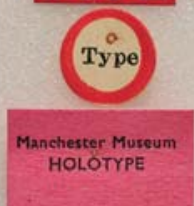

F2439.36

Figs 10-15. Holotypes of Passalidae in the collection of Manchester Museum. 10 - Leptaulax arrowi Hincks, 1933; 11 - Passalus beneshi Hincks, 1950 (now Pertinax beneshi); 12 - Passalus (Pertinax) cuneatus Hincks, 1950; 13 - Aulacocyclus gravelyi Dibb, 1933; 14 - Labienus horrelli Hincks, 1932; 15 - Cetejus lateralis Hincks, 1938. Scale bars: $1 \mathrm{~cm}$.

Рис. 10-15. Голотипы Passalidae в коллекции Манчестерского Музея. 10 - Leptaulax arrowi Hincks, 1933; 11 - Passalus beneshi Hincks, 1950 (в настоящее время Pertinax beneshi); 12 - Passalus (Pertinax) cuneatus Hincks, 1950; 13 - Aulacocyclus gravelyi Dibb, 1933; 14 — Labienus horrelli Hincks, 1932; 15 — Cetejus lateralis Hincks, 1938. Масштаб: 1 см. 
TYPE MATERIAL. Paratypes (2 ex), F2439.56-7.

LABEL DATA. Labienus / cheesmanae / Hincks Paratype / Det. / W. D. Hincks, Leeds // Papua: Ishurava / 3,000 ft. vii.1933 / L.E. Cheesman. / B.M. 1933-577.

CURRENT NOMENCLATURE. Passalinae, Macrolinini, Labienus cheesmanae Hincks, 1935.

REMARKS. Hincks [1935: 52] states, 'They [two new species] are included in a small but very interesting collection of Passalidae made by Miss L.E. Cheesman in New Guinea and sent by Mr. Arrow for determination.' The five examples of $L$. cheesmanae examined by Hincks (type and paratypes) were in the BMNH collection.

\section{cornutus Hincks et Dibb, (Notocetius)}

Notocetius cornutus Hincks et Dibb, 1935b: 273, figs 1-2. TYPE MATERIAL. Paratypes (2 ex), F2439.34-35.

LABEL DATA. Paratype / Notocetius / cornutus H \& D. / Mus. Hincks \& Dibb // Australie / Taeniocerus / deyrollei / Kaup // Ex Coll. / E. C. Horrell.

CURRENT NOMENCLATURE. Passalinae, Macrolinini, Austropassalus hultgreni Mjöberg, 1917.

REMARKS. 1. Notocetius cornutus was synonymised with Austropassalus hultgreni Mjöberg, 1917 by Hincks [1949: 64].

2. F2439.34 also has a handwritten note "?Ex Schill/ Coll." Hincks et Dibb's description [1935b: 272] states, 'They were received with the nucleus of our collection from Mr. E.C. Horrell, of Bradford, and, we believe, had formed part of the Schill collection*, a few boxes of which were acquired by Mr. Horrell. The labels bore the legend 'Taeniocerus deyrollei Kaup, Australie,' and as it was evident that the specimens were not the Aulacocycline T. deyrollei we were led to doubt the authenticity of the locality also..... one of us discovered another example of what appeared to be the same species in the British Museum collection. This bears a Queensland locality, and ...proves to be identical with our own.' The BMNH example was selected as the type.

\section{cuneatus Hincks, (Passalus)}

Fig. 12 .

Passalus cuneatus Hincks, 1950: 1043, fig. 2.

TYPE MATERIAL. Holotype ( $\left.\sigma^{7}\right)$, F2439.50.

LABEL DATA. Passalus (Pertinax) / cuneatus Hincks / Type / det. W.D. Hincks // Chiriqui / Panama // Ex Staudinger \& / Bang Haas, Dresden // O dissect / S. Boucher det. 2012.

CURRENT NOMENCLATURE. Passalinae, Passalini, Passalus (Pertinax) cuneatus Hincks, 1950.

\section{dreuxi Boucher, (Veturius)}

Veturius dreuxi Boucher, 2006: 470, figs 523-525.

TYPE MATERIAL. Paratypes (2 OO+), F2439.14-15.

LABEL DATA. F2439.14: Vet. (V.) / dreuxi / Paratype / S. Boucher det. 04 // Gonzales / Paraguay // Ex Staudinger \& Bang Haas, Dresden. // Mus: Hincks \& Dibb; F2439.15: As F2439.14 except locality - Coroico / Bolivia.

CURRENT NOMENCLATURE. Passalinae, Proculini, Veturius (Veturius) dreuxi Boucher, 2006.

REMARKS. 1. Placed in the ecuadoris species group by Boucher [2006].

2. Historical note in Boucher [2006: 471] that this species had been seen before by Hincks, who did not identify it or cite it in his publication on fauna of Bolivia [Hincks, 1934].

\section{ealaensis Hincks, (Didymus)}

Didymus ealaensis Hincks, 1933d: 63, figs 4, 9, 13. TYPE MATERIAL. Paratype, F2439.29.
LABEL DATA. Didymus / ealaensis n. sp. / Det. / W. D. Hincks, Leeds // Musée du Congo / Eala / 4 X 1931 / H. J. Bredo // Ex Staudinger \& Bang Haas, Dresden // Mus: Hincks \& Dibb.

CURRENT NOMENCLATURE. Passalinae, Solenocyclini, Didimus ealaensis Hincks, 1933.

REMARKS. Didymus was an erroneous spelling in the original description [Hincks, 1933d].

\section{gravelyi Dibb, (Aulacocyclus)}

Fig. 13.

Aulacocyclus gravelyi Dibb, 1933: 104.

TYPE MATERIAL. Holotype, F2439.2.

LABEL DATA. Aulacocyclus / gravelyi Dibb / (Type) / Det / JR Dibb. Leeds // C. Roussel / Australie // Ex. Coll Dr. Nodier, via J. Clermont, Paris. // 6064.

CURRENT NOMENCLATURE. Aulacocyclinae, Aulacocyclini, Aulacocyclus gravelyi Dibb, 1933.

REMARKS. Dibb [1938: 115] states that 'The two examples of this species in coll. Hincks et Dibb comprise the type and another, and neither specimen bears detailed locality label.'

\section{hebridalis Boucher, (Gonatas)}

Gonatas hebridalis Boucher, 1991: 364, figs 3-4, 7, 9

TYPE MATERIAL. Paratype, F2439.44.

LABEL DATA. Gonatas / hebridalis / Paratype / S. Boucher det. 91 // Nouvelles-Hébrides / I. Ambrym // Muséum Paris 1934 / E. Aubert de la Rue.

CURRENT NOMENCLATURE. Passalinae, Macrolinini, Gonatas hebridalis Boucher, 1991.

REMARKS. 1. Ambrym is one of the islands of Vanuatu, formerly known as New Hebrides.

2. Donated to MMUE by S. Boucher.

\section{hincksi Boucher, (Veturius (Veturius))} 313

Veturius (Veturius) hincksi Boucher, 2006: 400, figs 260, 302-

TYPE MATERIAL. Paratype ( $(+)$, F2439.18.

LABEL DATA. Veturius (V.) / hincksi / [ill.] Paratype $q / \mathrm{S}$. Boucher det. 04 // Ecuador / Pichin - Ayuriqui / 12-VII-87 / Legit: M. Ferro.

CURRENT NOMENCLATURE. Passalinae, Proculini, Veturius (Veturius) hincksi Boucher, 2006.

REMARKS. 1. Placed in the biapicalis species group by Boucher [2006].

2. Donated to MMUE by S. Boucher.

\section{hirsutus Hincks, (Leptaulax)}

Leptaulax hirsutus Hincks, 1956: 120.

TYPE MATERIAL. Paratype, F2439.46.

LABEL DATA. Leptaulax / hirsutus / Hincks / Paratype / det. W. D. Hincks // New Guinea / Koffena, Divid. / Range betw. / Asaro-Shimbu / Valley. 9700' / Moss forest. / 13.6.1955. // Coll Dr. J. J. H. / Szent-Ivany // Ex. Coll / Dept. Agr. / Pt. Moresby / No. 793.

CURRENT NOMENCLATURE. Passalinae, Leptaulacini, Leptaulax hirsutus Hincks, 1956.

REMARKS. Hincks [1956: 117] states, ‘... a small collection of Papuan Passalid beetles made by Dr. J.J.H. SzentIvany in moss forest at 8,000-9,400 ft., kindly sent for identification by Dr. W.J. Hall of the Commonwealth Institute of Entomology, is reported on in the present paper. Five species are represented, two of which appear to be undescribed. The types of the latter will be deposited in the British Museum (Natural History), the paratypes and the remaining specimens being returned to the Department of Agriculture, Port Moresby.'

* The Schill Coleoptera were auctioned by Stevens in 1909, vide W. Horn, Suppl. Ent. 12, 1926, p. 109; 17,1929 , p. 111. 


\section{horrelli Hincks, (Labienus)}

Fig. 14.

Labienus horrelli Hincks, 1932: 97, figs 1-2.

TYPE MATERIAL. Holotype, F2439.58; paratype, F2439.59.

LABEL DATA. Holotype F2439.58: Labienus horrelli / Hincks / Type / Stylops 1932 p // Sudest I. / Ex Coll. E.C. / Horrell / Mus. Hincks \& Dibb // 5071

Paratype F2439.59: Labienus horrelli / Hincks / Cotype / Stylops 1932 // Sudest I. / Ex Coll. E.C. / Horrell / Mus. Hincks \& Dibb // 5072

CURRENT NOMENCLATURE. Passalinae, Macrolinini, Labienus horrelli Hincks, 1932.

REMARKS. 1. Hincks [1932] refers to 'Two specimens from Sudest Island (ex Coll. E.C. Horrell) in my collection. Named after Mr E.C. Horrell of Bradford, through whose generosity and kindness I have been able to acquire much valuable material in the Passalidae and in other families'

2. Sudest Island now Vanatinae or Tagula, in Papua New Guinea.

\section{imitator Boucher, (Veturius)}

Veturius imitator Boucher, 2006: 408, fig.104, 263, 356-363. TYPE MATERIAL. Paratype (\$), F2439.16.

LABEL DATA. Vet. / imitator + / Paratype / S. Boucher det. 04 // Colombia / coll. DIA Entomologia / Hincks \& Dibb coll. // [illeg.]

CURRENT NOMENCLATURE. Passalinae, Proculini, Veturius (Veturius) imitator Boucher, 2006.

REMARKS. 1. Placed in the caquetaensis species group by Boucher [2006].

3. The original description [Boucher 2006: 408] provides locality information: 'Santander, Rionegro [N. Bucaramanga, > $1000 \mathrm{~m}$ ], Lmm [?] VII.1935 (MUHD 9)'. A recent communication from $\mathrm{S}$. Boucher indicates that this is the correct specimen but the label appears to be now missing.

\section{jamaicensis Hincks, (Paxillus)}

Paxillus jamaicensis Hincks, 1950: 1038, fig. 5.

TYPE MATERIAL. Paratype, F2439.21.

LABEL DATA. Paxillus / jamaicensis / Hincks Paratype / det. W. D. Hincks // B.W. I., Jamaica, / St. Andrew / Hardware Gap / c. 4000' 5.xii.46 / G. B. Thompson.

CURRENT NOMENCLATURE. Passalinae, Passalini, Paxillus jamaicensis Hincks, 1950

\section{lateralis Hincks, (Cetejus)}

Fig. 15.

Cetejus lateralis Hincks, 1938b: 16.

TYPE MATERIAL. Holotype, F2439.36; paratypes (2 우), F2439.37-8; paratype, F2439.39.

LABEL DATA. Holotype F2439.36: Cetejus / lateralis / Hincks / Type // Rawlinson Gb. / S. O. N. Guinea.

Paratype F2439.37: Cetejus / lateralis / Hincks / Para- / type // Bolan Gbg / N. Guinea // 6548 // Ex Staudinger \& / Bang Haas, Dresden // 0

Paratype F2439.38: Cetejus / lateralis / Hincks / Para- / type // Owgarra / B. N. Guinea / A.S. Meek // 5508 // Via Janson, London // 우 Paratype F2439.39: Cetejus / lateralis / Hincks / Para- / type // Finschhafen / D. N. Guinea.

CURRENT NOMENCLATURE. Passalinae, Macrolinini, Cetejus lateralis Hincks, 1938.

REMARKS. Hincks [1938b:16] refers to 5 paratypes but stated that one paratype would be deposited at BMNH. An MMUE working catalogue of 1982 lists four paratypes.

latericrinitus var. connatus Hincks, (Erionomus) Fig. 16.

Erionomus latericrinitus var. connatus Hincks, 1933a: 12, fig. 2.
TYPE MATERIAL. Holotype ( $\left.\sigma^{\top}\right)$, F2439.30

LABEL DATA. Var. connatus / Hincks Type // Dtsch. O. / Afrika // 5057 // Ex Staudinger \& Bang Haas, Dresden // Wings removed / to microslides.

CURRENT NOMENCLATURE. Passalinae, Solenocyclini, Erionomus latericrinitus var. connatus Hincks, 1933.

\section{luederwaldti Hincks, (Passalus)}

Fig. 17.

Passalus luederwaldti Hincks, 1940: 495.

TYPE MATERIAL. Holotype, F2439.23; paratype, F2439.24

LABEL DATA. Holotype F2439.23: Passalus / (Petrejus) / luederwaldti / Hincks / Type // Muzo / Columbia.

Paratype F2439.24: Passalus / luederwaldti / Hincks / Paratype // Villavicencio / Ost-Columbia.

Both specimens: Ex Staudinger \& Bang Haas, Dresden. / / Mus. Hincks and Dibb.

CURRENT NOMENCLATURE. Passalinae, Passalini, Passalus luederwaldti Hincks, 1940.

\section{mancus occidentalis Hincks, (Passalus)}

Fig. 18.

Passalus mancus occidentalis Hincks, 1950: 1041.

TYPE MATERIAL. Holotype, F2439.51; paratype, F2439.52

LABEL DATA. Holotype F2439.51: Passalus (Pertinax) / mancus Burm. ssp. / occidentalis Hincks / Type / det. W.D. Hincks // S. J. d. Chimbo / Ecuador.

Paratype F2439.52: As for holotype, except 'Paratype'.

CURRENT NOMENCLATURE. Passalinae, Passalini, Passalus mancus occidentalis Hincks, 1950.

REMARKS. S.J.d. Chimbo = San José de Chimbo, Bolívar, Ecuador.

\section{nigidioides Hincks, (Passalus)}

Fig. 19.

Passalus (Phoroneus) nigidioides Hincks, 1949: 62, Pl. V, figs 1-2. TYPE MATERIAL. Holotype, F2439.6; paratype, F2439.7.

LABEL DATA. F2439.6: Passalus nigidioides / Hincks ms / Type // La Conquista / Guatemala.

F2439.7: As for holotype, except 'Paratype'.

Both specimens: Ex Staudinger \& Bang Haas, Dresden / / Mus. Hincks and Dibb.

CURRENT NOMENCLATURE. Passalinae, Proculini, Undulifer nigidioides (Hincks, 1949).

REMARKS. Transferred to Pseudacanthus by Reyes Castillo, Schuster [1983: 53] and from Pseudacanthus to Undulifer by Boucher [2006: 345].

\section{nodifrons Dibb, (Passalus)}

Passalus nodifrons Dibb, 1948: 284, fig. 1.

TYPE MATERIAL. Paratype, F2439.22.

LABEL DATA. Passalus / (Pertinax) / nodifrons / Dibb / Paratype // La Paz Bol- / ivia. Rcd 2'28 / H. Clemens.

CURRENT NOMENCLATURE. Passalinae, Passalini, Passalus nodifrons Dibb, 1948.

REMARKS. Dibb [1948: 264] thanked '... Dr. E.A. Chapin and the authorities of the United States National Museum, Washington, for the loan of the specimens for determination and description.'

\section{oberthuri Hincks, (Publius)}

Fig. 20

Publius oberthuri Hincks, 1933b: 177.

TYPE MATERIAL. Holotype, F2439.19; paratype, F2439.20.

LABEL DATA. Holotype, F2439.19: Publius / oberthüri/Hincks 
1933 / Det. / W. D. Hincks, Leeds // Type // Santé [sic] Fé / de Bogota // via J. Clermont, Paris.

Paratype, F2439.20: Publius / oberthüri / Hincks 1932 / Det. /

W. D. Hincks, Leeds // Paratype // Villavicencio / Ost-Columbia //
Ex Staudinger \& Bang Haas, Dresden.

CURRENT NOMENCLATURE. Passalinae, Proculini, Veturius (Ouayana) oberthuri (Hincks, 1933).

REMARKS. Transferred by Boucher [2006: 550].
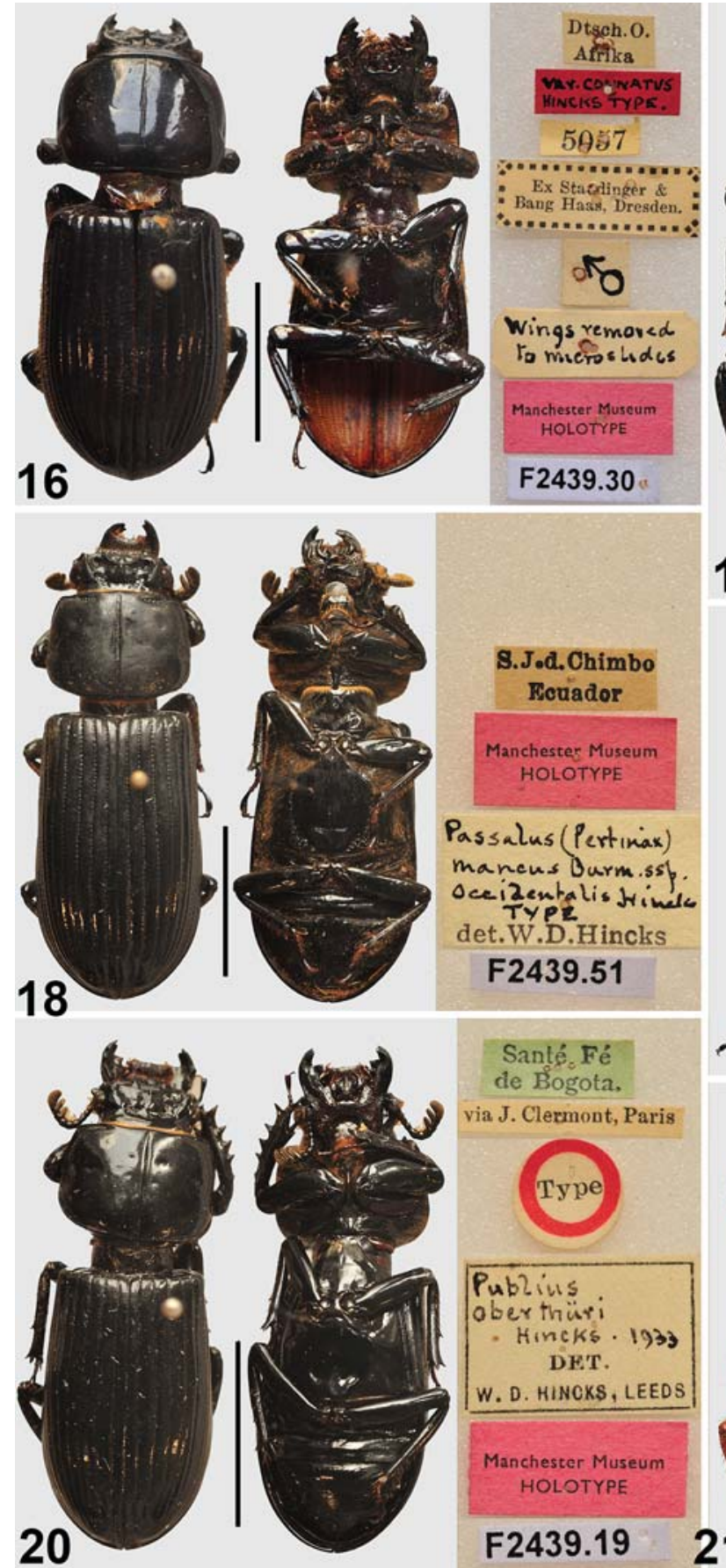

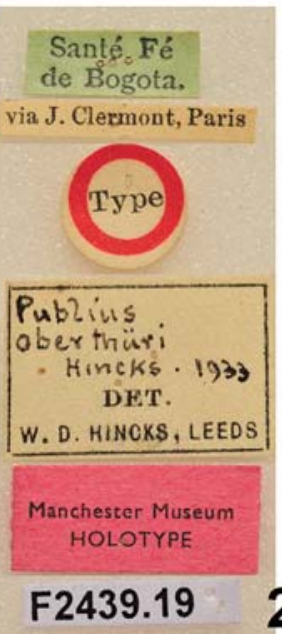

F2439.19
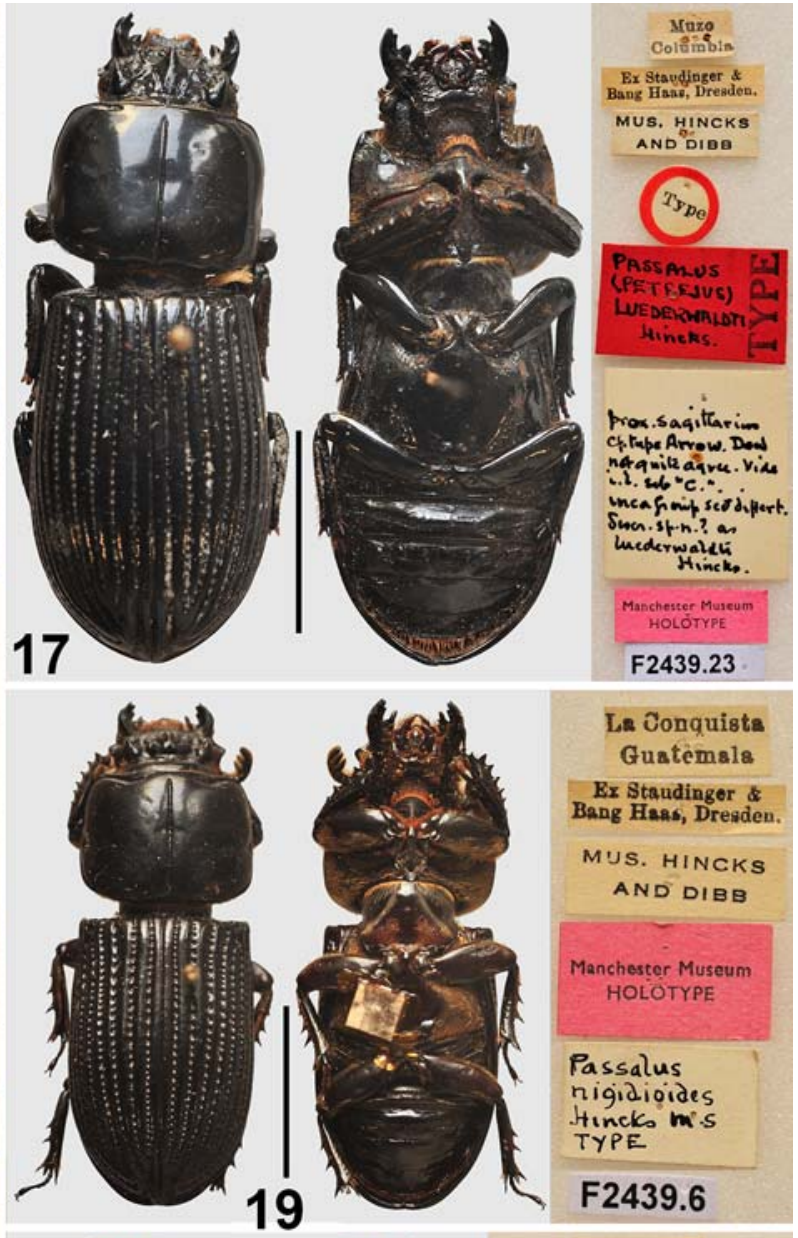

Jonquista Guatemsla

Ex Staudinger \& Bang Haas, Dreaden. MUS. HINCKS AND DIBB
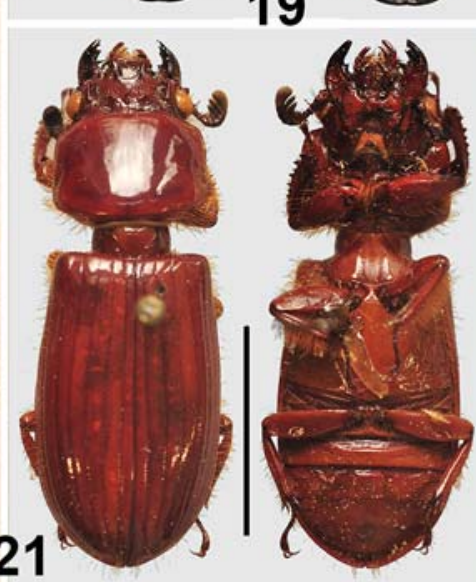

Figs 16-21. Holotypes of Passalidae in the collection of Manchester Museum. 16 - Erionomus latericrinitus var. connatus Hincks, 1933; 17 - Passalus luederwaldti Hincks, 1940; 18 - Passalus mancus occidentalis Hincks, 1950; 19 — Passalus nigidioides Hincks, 1949 (now Undulifer nigidioides); 20 - Publius oberthuri Hincks, 1933 (now Veturius (Ouayana) oberthuri); 21 — Aceraius parvulus Hincks, 1938 (now Ophrygonius minor). Scale bars - $1 \mathrm{~cm}$.

Рис. 16-21. Голотипы Passalidae в коллекции Манчестерского Музея. 16 - Erionomus latericrinitus var. connatus Hincks, 1933; 17 - Passalus luederwaldti Hincks, 1940; 18 - Passalus mancus occidentalis Hincks, 1950; 19 — Passalus nigidioides Hincks, 1949 (в настоящее время Undulifer nigidioides); 20 - Publius oberthuri Hincks, 1933 (в настоящее время Veturius (Ouayana) oberthuri); 21 Aceraius parvulus Hincks, 1938 (в настоящее время Ophrygonius minor). Масштаб — 1 см. 


\section{opalus Boucher, (Labienus)}

Labienus opalus Boucher, 1993a: 141, figs 15, 18, 20. TYPE MATERIAL. Paratype ( + ), F2439.43.

LABEL DATA. Labienus / opalus / Paratype + / S. Boucher det. 92 // Neuguinea / Ialibu V.1972 / G. Padma leg. // Ex. Coll. / E. Weinreich / in S. Boucher 87.

CURRENT NOMENCLATURE. Passalinae, Macrolinini, Labienus opalus Boucher, 1993.

REMARKS. Donated by S. Boucher to MMUE.

\section{papuanus Hincks, (Mastochilus)}

Mastochilus papuanus Hincks, 1956: 117. TYPE MATERIAL. Paratype, F2439.33.

LABEL DATA. Mastochilus / papuanus / Hincks Paratype / det W. D. Hincks // New Guinea / Daulo Pass / E. Highlands / 8000 moss-forest. 15.6.55.

CURRENT NOMENCLATURE. Passalinae, Macrolinini, Hincksius papuanus (Hincks, 1956).

REMARKS. 1. Transferred by Boucher [1993a: 133].

2. Hincks [1956: 118] gives the collector as Dr. J.J.H. Szent-Ivany. See Leptaulax hirsutus for same collection.

\section{paradoxus Hincks, (Cetejus)}

Cetejus paradoxus Hincks, 1937: 16, textfig.

TYPE MATERIAL. Paratype, F2439.40.

LABEL DATA. Cetejus / paradoxus / Hincks - Paratype / Det / W. D. Hincks, Leeds // Papua: Ishurava. / 3,000 ft vii.1933. / L.E. Cheesman. / B.M. 1933-577.

CURRENT NOMENCLATURE. Passalinae, Macrolinini, Cetejus paradoxus Hincks, 1937.

\section{parvulus Hincks, (Aceraius)}

Fig. 21.

Aceraius parvulus Hincks, 1938b: 15.

TYPE MATERIAL. Holotype, F2439.32.

LABEL DATA. Aceraius parvulus / Hincks n. sp / Type. // Ophrygonius minor / (Gravely, 1914) / det. M. Kon 1996 // Gunong / Inas / 3-4000 ft / Malay Pen. / Skeat / 30.XI.1899

CURRENT NOMENCLATURE. Passalinae, Macrolinini, Ophrygonius minor (Gravely, 1914).

REMARKS. 1. Aceraius parvulus was synonymised with Ophrygonius minor (Gravely, 1914) by Kon [2001: 108].

2. Hincks [1938b: 14--15] states that at the time the type was 'Unique in Cambridge Zoological Museum', and was sent for examination by 'G.A. Kerrich' (University Museum, Cambridge) [Possibly G.J. Kerrich, who was a curator at Cambridge, subsequently becoming Assistant Keeper of Entomology at Manchester Museum in 1938 and succeeded by Hincks in 1947].

\section{patalis Lewis, (Aulacocyclus)}

Aulacocyclus patalis Lewis, 1883: 341, figs 6-7.

TYPE MATERIAL. Syntype, F2439.3.

LABEL DATA. Cylindrocaulus / patalis, Lewis / co-type // Yuyama / 10.V-14.5.81 // Japan / G. Lewis / 1910-320. // 11.5.81.

CURRENT NOMENCLATURE. Aulacocyclinae, Ceracupini, Cylindrocaulus patalis (Lewis, 1883)

REMARKS. 1. Transferred to Cylindrocaulus by Gravely [1918: 21].

2. It is concluded that this specimen is a syntype since Lewis [1883: 341] did not specify a holotype, stating that he '.... took twenty specimens on the 11 th May, 1881 '. Gravely [1918: 21] did not comment on Lewis' material.

politus Hincks, (Proculejus)

Proculejus politus Hincks, 1953: 31, fig. 1. TYPE MATERIAL. Paratype, F2439.8.
LABEL DATA. Proculejus / politus Hincks / Paratype / det. W. D. Hincks // H. Mte. Cristo $(2200 \mathrm{~m})$ / El Salvador 4-8.6. / Dr. A. Zilch, S. $1951 / /$ Ogyges / R.C. 80.

CURRENT NOMENCLATURE. Passalinae, Proculini, Ogyges politus (Hincks, 1953).

REMARKS. 1. Transferred by Reyes-Castillo [1970: 176].

2. Hincks [1953: 29] states, 'An interesting group of 69 Passalidae collected during 1951 by Dr. A. Zilch in the Republic of El Salvador were kindly sent for examination by Dr. Elli Franz and at her request the following report has been prepared.' And, 'An interesting flightless species appears to be new to science and is described below as Proculejus politus n. sp. Except for a few duplicates in the writer's collection the specimens are in the SenckenbergMuseum.'

3. Locality is given in description as 'Cloud forest of Hacienda Mte. Christo’.

\section{procerus Hincks, (Passalus)}

Fig. 22.

Passalus procerus Hincks, 1940: 496.

TYPE MATERIAL. Holotype, F2439.25; paratypes (3), F2439.26-28.

LABEL DATA. Holotype, F2439.25: Passalus / procerus (Luedw. / m.s. [see REMARKS. below]) Hincks / [Petrejus] / Type // Itatiaya -1960m / Macieiras. / 21.7.33 / Macrolobus / procerus Lued. / J.F. Zikán // Mus. Hincks \& Dibb / Acc. 1938 - H20.

Paratypes, F2439.26-28: Same data as holotype.

CURRENT NOMENCLATURE. Passalinae, Passalini, Passalus procerus Hincks, 1940.

REMARKS. The species was described post-mortem by Luederwaldt [1941] under the same name, so Hincks had seen a specimen mss labelled as such by Luederwaldt. Luederwaldt died in 1934

\section{protomocoeloides Hincks, (Labienus)}

Fig. 23.

Labienus protomocoeloides Hincks, 1933c: 157.

TYPE MATERIAL. Holotype (†), F2439.54.

LABEL DATA. Labienus / protomocoeloides / Hincks / type // Finschhafen / D N Guin. // 5776 // Mus. Hincks \& Dibb // Labienus protomocol. Hincks / S. Boucher prep .

CURRENT NOMENCLATURE. Passalinae, Macrolinini, Labienus protomocoeloides Hincks, 1933.

REMARKS. Additional information in Hincks 1933c: 157: 'Finschhafen, ex-German New Guinea ... The type, unique in coll. Hincks \& Dibb (no. 5776).'

\section{striatulus Dibb, (Popilius)}

Popilius striatulus Dibb, 1940: 76

TYPE MATERIAL. Paratype, F2439.5.

LABEL DATA. Popilius / striatulus Dibb / Paratype / Det. J. R. Dibb // Aloag Ecua / 2900m. alt / F Campos R. // Ex Coll. U.S.N.M. Washington'

CURRENT NOMENCLATURE. Passalinae, Proculini, Odontotaenius striatulus (Dibb, 1940).

REMARKS. 1. Transferred by Reyes-Castillo [1970].

2. Dibb [1940: 76] states the species was '...described ... from five examples in the collection of the U.S. National Museum, Washington, which are temporarily in the writer's hands with other Passalidae sent for determination.'

\section{tarsipes Boucher, (Veturius (Veturius))}

Veturius (Veturius) tarsipes Boucher, 2006: 464, figs 505-509. TYPE MATERIAL. Paratype (†), F2439.17.

LABEL DATA. Vet $(V$.$) / tarsipes/Paratype / S. Boucher det. 04$ // Madre de Dios / S. O Peru // Ex Staudinger \& Bang Haas, Dresden // Mus. Hincks \& Dibb. 
CURRENT NOMENCLATURE. Passalinae, Proculini, Veturius (Veturius) tarsipes Boucher, 2006.

REMARKS. Identified as $O$ in the original description by Boucher 2006.
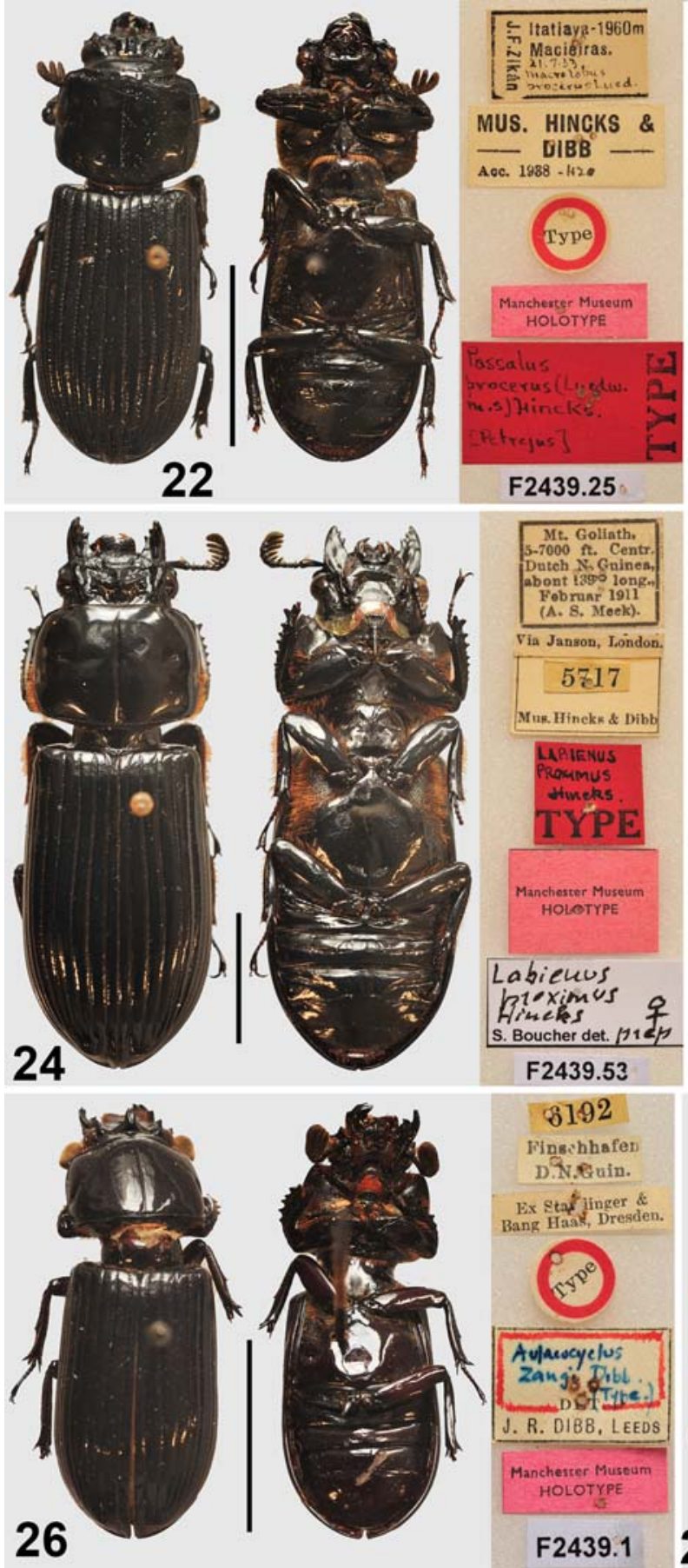

trigonophorus var. proximus Hincks, (Labienus) Fig. 24.

Labienus trigonophorus var. proximus Hincks, 1933c: 158, figs $1-3$.
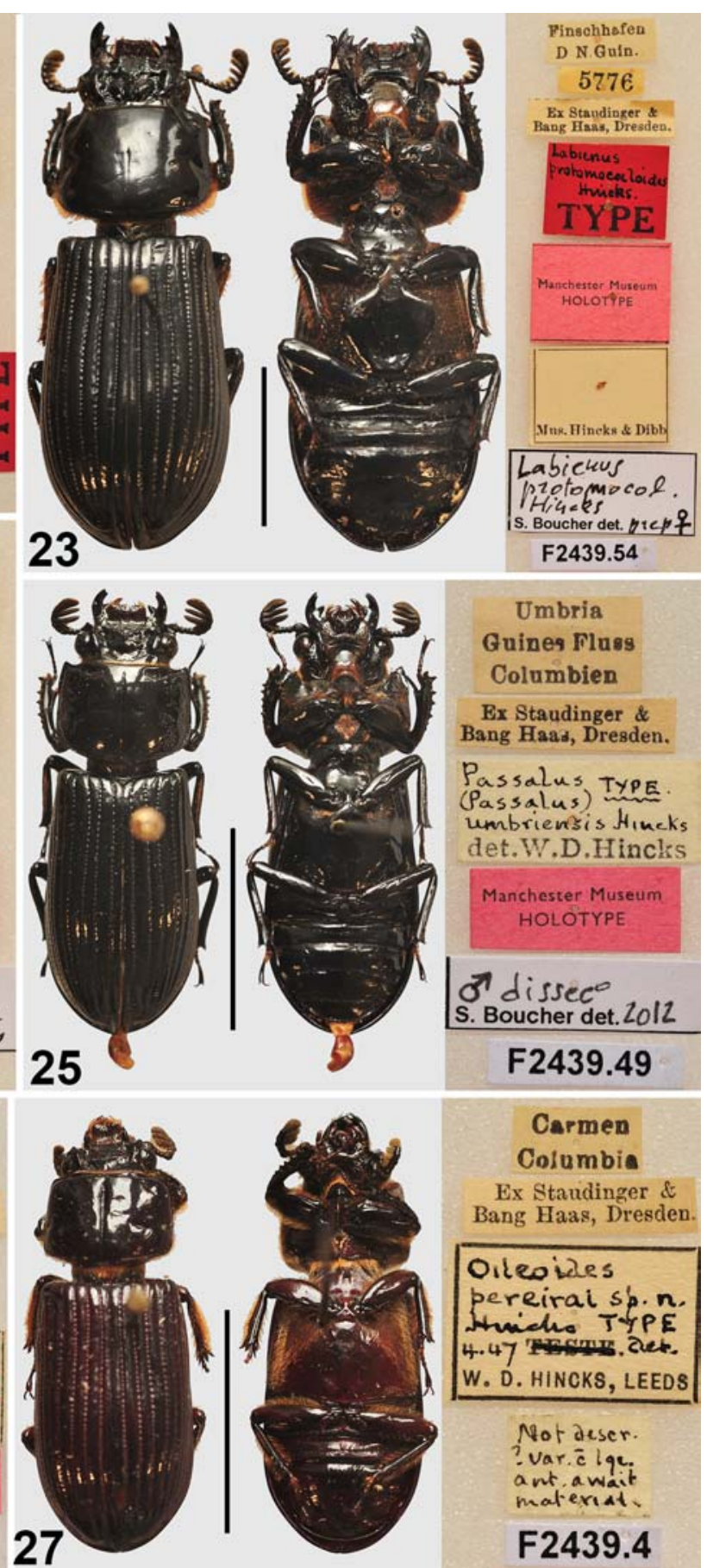

Carmen

Columbia

Ex Staudinger \& Bang Haas, Dresden.

\section{Oileoides}

pereiral sp. $n$. Hhicho THPE 4. 47 Thams. alet. W. D. HINCKS, LEEDS

Not deser. ? var. è lqe. materiat.

F2439.4

Figs 22-27. Holotypes of Passalidae in the collection of Manchester Museum. 22 - Passalus procerus Hincks, 1940; 23 - Labienus protomocoeloides Hincks, 1933; 24 — Labienus trigonophorus var. proximus Hincks, 1933 (now Labienus proximus); 25 — Passalus umbriensis Hincks, 1950 (now Pertinax umbriensis); 26 - Aulacocyclus zangi Dibb, 1935; 27 - Hincks' undescribed specimen 'Oileoides pereirai', labelled 'type'. Scale bars $-1 \mathrm{~cm}$.

Рис. 22-27. Голотипы Passalidae в коллекции Манчестерского Музея. 22 - Passalus procerus Hincks, 1940; 23 — Labienus protomocoeloides Hincks, 1933; 24 - Labienus trigonophorus var. proximus Hincks, 1933 (now Labienus proximus); 25 - Passalus umbriensis Hincks, 1950 (в настоящее время Pertinax umbriensis); 26 - Aulacocyclus zangi Dibb, 1935; 27 - Неописанный экземпляр Хинкса 'Oileoides pereirai', помеченный как 'тип'. Масштаб - 1 см. 
TYPE MATERIAL. Holotype (), F2439.53

LABEL DATA. Labienus / proximus / Hincks / Type // Mt. Goliath, / 5-7000 ft. Centr. / Dutch N. Guinea, / about $139^{\circ}$ long., Februar 1911 / (A. S. Meek) // Via Janson, London / 5717 / Mus. Hincks \& Dibb. // Labienus / proximus / Hincks + / S. Boucher det. prep.

CURRENT NOMENCLATURE. Passalinae, Macrolinini, Labienus proximus Hincks, 1933 [Hincks, Dibb, 1958: 26].

REMARKS. Hincks [1933c: 158] refers to the 'Type, unique in coll. Hincks \& Dibb (no. 5717)'.

\section{truncatus Hincks, (Labienus)}

Labienus truncatus Hincks, 1938a: 176, fig. 1.

TYPE MATERIAL. Paratypes (2), F2439.41-42.

LABEL DATA. F2439.41: Labienus / truncatus Hincks. / Paratype / Det. W. D. Hincks. Leeds // Dutch New Guinea: / Mt Cyclops. / 3,500 ft iii.1936 / L. E. Cheesman./ B.M. 1936-271// Mus. Hincks \& / Dibb / Acc. 1938-H14.

F2439.42: As F2439.41 except locality - Cyclops Mts., Mt. Lina.

CURRENT NOMENCLATURE. Passalinae, Macrolinini, Labienus truncatus Hincks, 1938.

\section{umbriensis Hincks, (Passalus)}

Fig. 25.

Passalus umbriensis Hincks, 1950: 1044, fig. 3.

TYPE MATERIAL. Holotype ( $\left.\sigma^{7}\right)$, F2439.49.

LABEL DATA. Passalus Type / (Passalus) / umbriensis Hincks / det. W.D. Hincks // Umbria / Guinea Fluss / Columbien // Ex Staudinger \& / Bang Haas, Dresden. // O dissect / S. Boucher det. 2012.

CURRENT NOMENCLATURE. Passalinae, Passalini, Pertinax umbriensis (Hincks, 1950).

REMARKS. Transferred to Pertinax (genus) by Boucher [2015: 118].

\section{urus Heller, (Macrolinus)}

Macrolinus urus Heller, 1898: 23

TYPE MATERIAL. Syntype (see REMARKS.), F2439.64

LABEL DATA. Macrolinus / urus Heller / ex typis! / Scrip. R. Oberthür // S. Celebes / Bua-Kraeng / 5000’ Febr: 1896 / H Fruhstorfer // Ex Coll. R. Oberthür. / Mus. Hincks \& Dibb

CURRENT NOMENCLATURE. Passalinae, Macrolinini, Macrolinus urus Heller, 1898.

REMARKS. It appears the specimen was sent by Oberthür to Hincks in 1933 (MMUE Hincks Archive No. 420). Heller's description [1898] did not state explicitly the number of specimens examined, but from his references to material from Dresden and Tring (UK) museums and the range of measurements given, at least two specimens were examined. Notes on the labels 'Ex. Coll. R. Oberthür' and 'Scrip. R. Oberthür' are in Hincks' handwriting.

\section{vanuatuensis Boucher, (Gonatas)}

Gonatas vanuatuensis Boucher, 1991: 367, figs 5-6, 8-9. TYPE MATERIAL. Paratype, F2439.45.

LABEL DATA. Gonatas / vanuatuensis / Paratype / S. Boucher det. 91 // Nouvelles-Hébrides / I. Ambrym // Muséum Paris / 193? [illeg.] / E. Aubert de la Rue.

CURRENT NOMENCLATURE. Passalinae, Macrolinini, Gonatas vanuatuensis Boucher, 1991.

REMARKS. 1. Ambrym is one of the islands of Vanuatu, formerly known as New Hebrides.

2. Boucher [1991: 367] gives dates of '1935-1936' for all specimens from this locality.

3. Donated to MMUE by S. Boucher. zangi Dibb, (Aulacocyclus)

Fig. 26.

Aulacocyclus zangi Dibb, 1935: 230, figs 1-2.

TYPE MATERIAL. Holotype, F2439.1.

LABEL DATA. Aulacocyclus / zangi Dibb / (Type) / Det / JR Dibb. Leeds // Finschhafen / D.N. Guin. // Ex Staudinger \& Bang Haas, Dresden.

CURRENT NOMENCLATURE. Aulacocyclinae, Aulacocyclini, Aulacocyclus zangi Dibb, 1935.

REMARKS. Additional information in Dibb (1935: 231): 'Type: unique in coll. Hincks \& Dibb (no. 6102)'.

\section{Other material}

The collection also contains a specimen labelled as type, but for which the author is unable to find any published reference - 'Oileoides pereirai Hincks', F2439.4. Hincks appears to have determined it to be a new species but not published a description (Fig. 27).

LABEL DATA: Oileoides / pereirai sp. n. / Hincks Type / 4.47 det. / W. D. Hincks, Leeds. // Carmen / Columbia.

\section{Discussion}

The number of specimens was found to be almost double the previously published figure of 4,259 specimens [Higham, 2012], which it is likely did not include the undetermined or partially determined material in store boxes. The number of species and subspecies is also increased by $15 \%$, largely as a result of SE Asia material identified for MMUE by M. Kon (Japan) in 2014-2015. The collection represents about $40 \%$ of the described world fauna, which validates the time required to undertake such an exercise by highlighting and promoting the usefulness of the collection as a resource.

The MMUE Passalidae collection is open to all researchers, who are invited to use it.

ACKNOWLEDGMENTS. I wish to thank Dr. Dmitri Logunov (Manchester Museum, UK) for the opportunity to work on this collection, for his advice, and for processing the holotype photographs; Philip Rispin (Manchester Museum, UK) for the use of his equipment, time and skill in photographing the specimens; Dr. Stéphane Boucher (Muséum national d'Histoire naturelle, Paris) for his taxonomic help and Prof. Masahiro Kon of Japan for the identification of some undetermined Passalidae specimens from SE Asia. Thanks are due to Pierre Oger of France and Johan van Keer of Belgium for their help in deciphering and translating the handwriting of René Oberthür and to Rebecca Machin, Leeds City Museum, UK, for access to Hincks archives and specimens.

\section{References}

Alberti S.J.M.M. 2009. Nature and Culture. Objects, disciplines and the Manchester Museum. Manchester University Press. 239 pp. Boucher S. 1991. Les Passalides de l'Archipel du Vanuatu. Remarques faunistiques et biogéographiques; comparaison avec la NouvelleCalédonie (Coleoptera: Passalidae) // Annales de la Société entomologique de France (N.S.). Vol.27. No.1. P.361-374.

Boucher S. 1993a. Nouveaux Passalinae néo-guinéens: Hincksius n. gen., Pseudepisphenus Gravely, Cetejus Kaup et Labienus Kaup (Coleoptera, Passalidae) // Revue Francaise d'Entomologie (N.S.). Vol.15. No.3. P.131-143. 
Boucher S. 1993b. Référence spéciale sur les caractères morphologiques-clés séparant les genres indo-malais Aceraius Kaup et Ophrygonius Zang, avec les descriptions de sept nouveaux Ophrygonius (Coleoptera, Passalidae) // Nouvelle Revue d'Entomologie. Vol.10. No.2. P.153-172.

Boucher S. 2006. Évolution et phylogénie des Coléoptères Passalidae (Scarabaeoidea). Les taxons du groupe famille. La tribu des Proculini et son complexe Veturius // Annales de la Société entomologique de France (N.S.). Vol.41. No.3-4 [2005]. P.239604. http://dx.doi.org/10.1080/00379271.2005.10697444.

Boucher S. 2015. Splitting of the polyphyletic genus Passalus Fabricius, s. auct. I. (Coleoptera, Passalidae) // Bulletin de la Société entomologique de France. Vol.120. No.1. P.113-120.

D'Albertis L.M. 1880. New Guinea: What I did and what I saw. Sampson Low, Marston, Searle \& Rivington, London Vol.2. P.1-406; online at: http://papuaweb.org/dlib/bk2/dalbertis/ index.html.

Dibb J.R. 1933. A new species of Aulacocyclus (Passalidae) from Australia // The Entomologist's Monthly Magazine. Vol.69. P.103-104.

Dibb J.R. 1935. Further notes on Aulacocyclus (Col., Passalidae) // Proceedings of the Royal Entomological Society of London. Series B, Taxonomy. Vol.4. P.227-233. http://dx.doi:10.1111/ j.1365-3113.1935.tb00650.x.

Dibb J.R. 1938. Synopsis of Australian Passalidae (Coleoptera) // Transactions of the Royal Entomological Society of London. Vol.87. No.4. P.103-124. http://dx.doi.org/10.1111/j.13652311.1938.tb00092.x

Dibb J.R. 1940. Further notes on the genus Popilius Kaup (Col., Passalidae) // Entomologist's Monthly Magazine. Vol.4. No.1. P.76-77.

Dibb J.R. 1948. Description of a new species of Passalidae (Col.) from Bolivia. The Entomologist's Monthly Magazine. Vol.4. No.9. P.284.

Gilbert P. 2007. A Source Book for Biographical Literature on Entomologists. Backhuys Publishers, Leiden. 695 pp.

Gravely F.H. 1918. A Contribution towards the Revision of the Passalidae of the World // Memoirs of the Indian Museum, Calcutta. Vol.7. No.1. P.1-148. http://dx.doi.org/10.5962/ bhl.title.9238.

Heller K.M. 1898. Neue käfer von Celebes III // Abhandlungen und Berichte des Königlichen Zoologischen und AnthropologischEthnographischen Museums zu Dresden. Bd.7 Hft.3. S.1-41; online at http://www.archive.org/stream/mobot31753003648687\#page/n118/mode/1up [accessed 27.5.2016].

Higham D. 2012. The Manchester Museum's Cassidinae Collection (Coleoptera: Chrysomelidae: Cassidinae)//Genus. Vol.23. No.3. P.341-361. Available at http://www.biol.uni.wroc.pl/cassidae/ Higham_Manchester\%20Museum\%20Cassidinae\%20Collection.pdf. [accessed 8.10.2014].

Hincks W.D. 1932. Notes on Passalidae (Col.) from Sudest Island // Stylops. Vol.1. No.5. P.97-98. http://dx.doi.org/10.1111/j.13653113.1932.tb01361.x.

Hincks W.D. 1933a. Notes on the Passalidae. No. 2. Flightless Species // The Entomologist's Monthly Magazine. Vol.69. P.1013.

Hincks W.D. 1933b. Notes on the Passalidae. No. 3. New synonymy and some little-known species with the description of a new Publius //The Entomologist's Monthly Magazine. Vol.69. P.175182.

Hincks W.D. 1933c. On the species of Labienus (Col. Passalidae) related to L. trigonophorus, Zang // Stylops. Vol.2. No.7. P.156158. http://dx.doi.org/10.1111/j.1365-3113.1993.tb00992.x.

Hincks W.D. 1933d. The Passalidae of the Belgian Congo // Transactions of the Royal Entomological Society London. Vol.81. No.1. P.53-65. http://dx.doi.org/10.1111/j.1365-2311. 1933.tb00398.x.

Hincks W.D. 1934. Notes on the Passalidae (Coleoptera). No 5. Synonymic Notes, with the Descriptions of a New Genus and New Species // The Entomologist's Monthly Magazine. Vol.20. P.151-157.

Hincks W.D. 1935. Notes on the Passalidae (Coleoptera). No. 5. Synonymic Notes, with the descriptions of a new Genus and new
Species // The Entomologist's Monthly Magazine. Vol.71. P.5054.

Hincks W.D. 1937. Passalidae (Col.) from Papua collected by Miss L.E. Cheesman // Nova Guinea New Series. Vol.1. P.112-124.

Hincks W.D. 1938a. Passalidae (Coleoptera) from the Cyclops Mountains, Dutch New Guinea // The Entomologist's Monthly Magazine. Vol.74. P.175-177.

Hincks W.D. 1938b. Some new Macrolininae (Coleoptera: Passalidae) // Proceedings of the Royal Entomological Society of London (B). Vol.7. No.1. P.14-17 http://dx.doi.org/10.1111/ j.1365-3113.1938.tb01226.x.

Hincks W.D. 1940. Preliminary Key to the "Petrejus" Section of the Genus Passalus (Coleoptera, Passalidae)// The Annals and Magazine of Natural History. Vol.11. No.6. P.486-496.

Hincks W.D. 1949. Systematic and Synonymic Notes on Passalidae (Col.) // The Annals and Magazine of Natural History. Vol.12. No.2. P.56-64. http://dx.doi.org/10.1080/00222934908653958.

Hincks W.D. 1950. Systematic and Faunistic Notes on American Passalidae (Col.) // The Annals and Magazine of Natural History. Vol.12. No.3. P.1033-1047.

Hincks W.D. 1953. The Passalidae (Ins. Col.) of El Salvador // Senckenbergiana (Frankfurt). Bd.34. Hft.1/3. S.29-35.

Hincks W.D. 1956. Notes on Passalid Coleoptera from New Guinea with the descriptions of two new species // Proceedings of the Royal Entomological Society of London (B). Vol.25. No.7-8. P.117-120. http://dx.doi.org/10.1111/j.1365-3113.1956.tb01107.x.

Hincks W.D., Dibb J.R. 1935a. Passalidae // Coleopterorum Catalogus. W. Junk, S. Schenkling. Gravenhage. Vol.142. P.1-118.

Hincks W.D., Dibb J.R. 1935b. A new genus and species of Passalidae (Col.) from Australia // Entomologist's Monthly Magazine. Vol.71. P.272-274.

Hincks W.D., Dibb J.R. 1958. Supplementa. Passalidae. Coleopterorum Catalogus. W. Junk, J. Schenkling. Gravenhage. 33 pp.

Johnson C. 1996. The Manchester Museum Department of Entomology // In: Underwood R. (ed.) The Raven Entomological and Natural History Society, Fifty Years, 1946-1996. The Raven Entomological and Natural History Society. P.202-207.

Kloet G.S. 1961. Obituary. Walter Douglas Hincks // Entomologist. Vol.94. No.1179. P.181-183.

Kon M. 2001. Redescription of Ophrygonius minor (Gravely) (Coleoptera, Passalidae) with a New Synonym // Special Publication of the Japan Coleopterological Society. Vol.1. P.107-109.

Kon M., Araya K., Johki, Y. 2016. Re-evaluation of the taxonomic status of Leptaulax niae Kuwert (Coleoptera, Passalidae) // Kogane. Vol.18. P.76-78.

Kon M., Johki Y. 2004. A Redescription of Leptaulax arrowi (Coleoptera, Passalidae) based on the holotype // Elytra. Vol.32. No.2. P.337-341.

Lawley M. 2106. A social and biographical history of British and Irish Field-Bryologists; online at http:// britishbryologicalsociety.org.uk/ [Accessed 20 Oct. 2016].

Leeds University Library. 2016. James Digby Firth (1877-1968); online at https://library.leeds.ac.uk/special-collections/collection/1475/james_digby_firth_1877-1968 [Accessed 16 Oct. 2016].

Lees A.D. 1974. The President's REMARKS. // Proceedings of the Royal Entomological Society of London (C). Vol.38. P.58-59.

Lewis G. 1883. On the Lucanidae of Japan // Transactions of the Entomological Society of London. Vol.31. No.3. P.333-342; online at http://www.archive.org/stream/transactionsofen 1883roya\#page/333/mode/1up [accessed 27.5.2016]

Logunov D.V. 2010. The Manchester Museum's Entomology Collections // Antenna. No.34. P.163-167.

Logunov D.V. 2012. British entomology collections of the Manchester Museum // J. Lanc. \& Chesh. Entomol. Soc. No.133-134. (2009-2010). P.20-44.

Logunov D.V., Merriman N. (eds). 2012. The Manchester Museum: window to the world. London: Third Millenium Ltd. $156 \mathrm{pp}$.

Luederwaldt H. 1931. Monographia dos Passalideos do Brasil (Col.) // Revista do Museu Paulista. Vol.17. P.1-263.

Luederwaldt H. 1934. Revisao do genero Paxillus // Revista do Museu Paulista. Vol.18. P.357-369. 
Luederwaldt H. 1941. Passalídeos americanos // Arquivos de Zoologia do Estado de São Paulo. Vol.3. P.75-91.

Miles C. 2015. The Earwig Collection (Dermaptera) of the Manchester Museum, UK, with a complete type catalogue // European Journal of Taxonomy. No.141. P.1-183. http://dx.doi.org/ 10.5852/ejt.2015.141

Murray C.C. 1938. Beetles aren't as black as they're painted. Yorkshire Evening News.

Norris A. 1995. Leeds City Museum - its Natural History Collections Part 2 : The Invertebrates // The Biology Curator. Vol.4. P.19-24; online at http://www.natsca.org/sites/default/files/publicationsfull/The-Biology-Curator-Issue 4.pdf [Accessed 17 Jun 2016].

Report 1960-61. The Manchester Museum. The University of Manchester. Manchester: Morris \& Yeaman. 27 pp.
Reyes-Castillo P. 1970. Coleoptera, Passalidae: Morfología y división en grandes grupos. Géneros Americanos // Folia Entomologica Mexicana. Vol.20-22. P.1-240.

Reyes-Castillo P., Schuster J.C. 1983. Notes on some Mesoamerican Passalidae (Coleoptera): Petrejoides and Pseudacanthus // The Coleopterists Bulletin. Vol.37. No.1. P.49-54.

Schoolmeesters P. 2016. Scarabs: World Scarabaeidae Database (version Jul 2016) // In: Species 2000 \& ITIS Catalogue of Life, 28th September 2016 (Roskov Y., Abucay L., Orrell T., Nicolson D., Flann C., Bailly N., Kirk P., Bourgoin T., DeWalt R.E., Decock W., De Wever A., eds). Digital resource at www.catalogueoflife.org/col. Species 2000: Naturalis, Leiden, the Netherlands. ISSN 2405-8858. 